\title{
Tort Liability, Combatant ACTIVITIES, AND THE Question OF OVER-DeTerRence
}

by

\author{
Haim Abraham*
}

[This is the accepted manuscript version. The final version is published in Law \& Social Inquiry, and is available here - https://www.cambridge.org/core/journals/law-and-social-inquiry/article/abs/tortliability-combatant-activities-and-the-question-ofoverdeterrence/C4B75513557C9A59C5683217155DDB23]

\begin{abstract}
Immunity from tort liability for losses that are inflicted during warfare is often justified by a supposedly intuitive concern: without immunity, states and combatants will be overdeterred from engaging in combat. In this paper, I test this common perception using three frameworks. First, I theoretically analyze the impact of tort liability on relevant state actors' incentives to conduct combatant activities. This analysis suggests that tort law is likely to under-deter state actors in relation to their decision on whether and how to engage in warfare. Second, I test the conclusion that tort law under-deters state actors through an original mixed-methods exploratory research, using Israel as a test case. My findings reveal that while tort liability under-deters state actors from engaging in warfare, it can prompt them to implement regulatory measures to minimize the State's liability. Third, I offer a legal history analysis that seeks to understand why Israel established an immunity from tort liability for losses it inflicts during combat in 1951, and why and how this immunity has expanded since. I show that as the Israel-Palestine conflict prolonged
\end{abstract}


and intensified, state actors began viewing Palestinians' tort claims as a civilian means of warfare, and immunity from liability as the weapon needed for defending Israel's interests.

\section{INTRODUCTION}

It has long been argued that one of tort law's key functions is to deter potential tortfeasors from acting without due care. Yet, tort law's ability to deter presents a challenge. If the incentives are too strong, individuals might avoid taking actions, even when such actions will not result in a wrong, as they will be over-deterred. Contrastingly, if the incentives are too weak, individuals might act without taking due care, and thus increasing the likelihood that their actions will result in wrongdoing as they will be under-deterred. A prime example of this challenge arises in the context of combat activities. Legislatures, courts, and scholars have asserted that if combatants are not afforded complete immunity from tort liability for losses they inflict during warfare, then they will refrain from engaging in combat or from doing all that they can to achieve their military goals (Koohi v. United States, 1330-31; Saleh v. Titan Corp., 18; Jamal Kasam Bani Uda v. Israel, 5; The Estate of Hardan v. Israel, 14; Jacob 2003, 129-30). A 'combatant activities exception' to the tort liability of states is, therefore, justified, as it prevents combatants and states from being overdeterred. ${ }^{1}$ In this paper, I challenge these accounts and justifications, using a novel empirical examination of tort liability's ability to deter state actors from engaging in warfare.

The combatant activities exception can be found in many common law jurisdictions, ${ }^{2}$ and it stands against a general trend that began in the mid- $20^{\text {th }}$ century of eliminating states' and public officials' immunities (Kerr, Olivo, and Kurtz 2014, 75; Bradley and Bell 1991, 15; Harlow 2004, 23). The fear of over-deterring combatants is based on the notion that public officials and bodies might bear the risks of their activities, but they generally do not gain the benefits of their activities 
in the same way that private individuals do. This incentive scheme raises the concern that public officials and bodies might be more prone to risk-averse behavior, causing them to act overcautiously and to fall short of fulfilling their public functions properly (Schuck 1983, 68; Fairgrieve 2002, 483; Surma 2002, 390). However, thus far, no empirical evidence has been offered in support of the argument that tort liability will over-deter public officials, and a theoretical analysis of deterrence points to the contrary conclusion.

In this paper, I empirically examine the assertion that tort liability for losses that are inflicted during warfare will result in over-deterrence. Through this examination, I offer substantial insights about the implications of imposing tort liability on public officials and bodies for military actions. I demonstrate that the common instrumental justification for the combatant activities exception does not align with the theoretical underpinnings of deterrence, and that there are indications that, in this context, tort liability will not result in over-deterrence. I also offer an innovative legal history analysis of the causes and motivations of the development of Israel's immunity from tort liability for losses it inflicts during warfare from 1951 to 2021 . This analysis indicates that motivations of state actors developed, at least in part, in response to and alongside changes in the character and intensity of the conflict between Israel and Palestine. As military forces were being used to perform policing and counter-terrorism activities in the Gaza Strip and the West Bank, state actors began viewing the Palestinian civilian population as an enemy and tort claims as a means of continuing warfare through civil litigation. Israel's immunity from liability was expanded not because of a fear of deterring combatants from engaging in battle, but as a form of supporting this form of "combat".

In doing so, this study sheds new light on two factors that are currently mis-conceptualized: the identity of relevant state actors, and their incentives for action or inaction in relation to 
engagement in battle. Courts and scholars' theoretical concern with over-deterrence is made by either focusing on the effects of an imposition of tort liability on the state, as if it was an autonomous actor, or on its combatants. Furthermore, the theoretical concern with over-deterrence seems to assume that the risks that are associated with liability are deemed to be at least as important as the security interests of the state and its agents. Yet, theorizing deterrence in this way disregards the fact that states can only act through their public officials. It also overlooks the possibility that public officials, who are not combatants but can influence if and how to engage in combat, could be over-deterred. Additionally, the assumption that the risk of tort liability is as important as security risks seems to be counterintuitive. Rather, security interests are likely to take precedence over other liability-related considerations, and so the liability-related considerations should have little to no effect on the decision to engage in combatant activities. In this sense, this study not only creates a dataset of tort liability's effects on state actors in relation to combatant activities, but also adds to the theoretical discourse on the role and scope of tort liability's deterring effects on public actors.

To achieve these objectives, I offer an exploratory research example using both quantitative and qualitative methods and focusing on Israel as a test case. My analysis is composed of an original empirical survey of 320 Israeli combatants; 13 in-depth, semi-structured interviews with members of the Knesset (the Parliament of Israel), high-ranking officers, legal advisors to the Israel Defense Forces ("IDF") and the Ministry of Defense ("MoD"), and state and district attorneys; ${ }^{3}$ an evaluation of the explanatory notes and protocols regarding the legislative amendments of the exception by the Israeli legislature; and additional secondary sources in relation to state actors' incentives to engage in combat or expand the combatant activities exception.

Israel provides a rich legislative history regarding the combatant activities exception that 
cannot be found in other jurisdictions. In Canada and the United States, for example, the rationale for enacting the exception is non-existent, and while in Australia and the United Kingdom the exception is a creation of the common law, the courts have not provided a fully fleshed-out justification for it (Johnson v. United States, 769; Ibrahim v. Titan Corp., 18; Saleh v. Titan Corp., 120; Canada, Parliament, House of Commons Debates, 3332; Shaw Savill \& Albion Co. v. Commonwealth, 361-63; Mulcahy v. Minister of Defence, 748-49). In contrast, Israel offers an abundance of materials. When Israel was established in 1948, it barred all tort claims against the State and its officials for two reasons. First, it feared that its public officials were not experienced enough, and are therefore likely to bring about a significant number of injuries (Protocol 185, 2112). Second, it assumed that individuals are likely to sue the state for the actions of its inexperienced officials, which would result in mass debt that the State could not repay (Id). However, by 1952 it enacted the State Wrongs (Civil Liability) Act, which both enables the State to be held tortiously liable, and immunizes it against any tortious liability for losses related to combatant activities. Unlike other jurisdictions, the Israeli legislature amended the scope of the exception three times, providing some insight in relation to the motives for the exception through the Bills' explanatory notes and protocols from the Israeli Parliament's Constitution, Law, and Justice Committee in which the amendments were discussed.

Furthermore, Israeli courts interpreted the applicability, scope, and rationale of the exception in over 290 cases $^{4}$ - more than the Australian, Canadian, U.K. and U.S. analyses of the topic combined - and have continuously broadened the interpretation of its scope. Plaintiffs in these cases are civilians, and on rare occasions corporations, that sustained a loss due to the operations of Israel's security forces, and the defendant is the State. The vast majority of plaintiffs are non-nationals Palestinians, although Israeli and other foreign nationals have also brought tort 
claims in this context on occasion. Causes of actions are mostly concerned with negligence and trespass to person and property that arise in a range of activities, either within Israel or in the Gaza Strip and the West Bank. These activities include, inter alia, counter-terrorism warfare, operation of checkpoints and policing activities by the military, and even traffic accidents of combatants driving on duty.

The paper proceeds as follows. In section II, I examine whether an imposition of tort liability will result in over-deterrence from a theoretical standpoint. I identify three relevant groups of state actors, who participate in the decision-making process on whether and how to engage in combat, and who could be deterred from an imposition of tortious liability: politicians, combatants, and government attorneys. I conclude that over-deterrence of these actors seems improbable as the necessary elements for deterrence (ability to choose course of action, information on risks and costs, and internalization of liability costs) are absent or non-operative in relation to combat. In section III, I test this conclusion using quantitative and qualitative methods, assessing state actors' deterrence from hypothetical impositions of liability, and the legal history of the establishment and expansion of the combatant activities exception in Israel. An analysis of the collected data suggests that an imposition of liability for losses that are inflicted during battle under-deters the relevant state actors from engaging in belligerent activities. Yet, tort litigation and liability had a secondary side-effect on politicians and government attorneys, as it prompted them to initiate and adopt legal amendments that greatly restrict potential plaintiffs' access to effective remedies. Section IV concludes by suggesting that the beliefs which ground the justifications of the combatant activities exception should be revisited. The findings of this study indicate that the minimization of tort liability was driven primarily by a desire to limit courts' ability to hold that the State inflicted a wrongful loss, rather than a fear of over-deterring combatants or a concern that tort suits will prove 
too costly for the State to bear. Additionally, while tort liability and litigation did not deter state actors from engaging in wrongful combatant activities, they did have an important regulatory sideeffect as tort liability and litigation seem to have prompted state actors to expand the scope of the immunity from liability. Given these findings, it is difficult to defend the combatant activities exception through the concept of over-deterrence.

\section{OVER-DETERRENCE OF COMBATANT ACTIVITIES: A THEORETICAL} ASSESSMENT

The existence of the combatant activities exception is often justified on the grounds that liability would over-deter states and combatants, causing them to either refrain from engaging in belligerent activities altogether, or to avoid using all the means at their disposal. ${ }^{5}$ For instance, in the Koohi case, which to date provides the most exhaustive analysis of the exception's rationales given by a court, Reinhardt J. held that

Tort law is based in part on the theory that the prospect of liability makes the actor more careful...Congress certainly did not want our military personnel to exercise great caution at a time when bold and imaginative measures might be necessary to overcome enemy forces; nor did it want our soldiers, sailors, or airmen to be concerned about the possibility of tort liability when making life or death decisions in the midst of combat (Koohi v. United States, 1330-31). ${ }^{6}$

Reinhardt J.'s argument illustrates an additional point that is common to both courts and academic writings on this topic: they often consider the deterring effects of tort liability either on the state as a single entity or on combatants as the only relevant state actors. Yet, the state is 
comprised of various groups of actors, each of whom might have different considerations and incentives. In the context of belligerent activities, there are three relevant groups of state actors who play an active part in the decision on whether and how to engage in battle: politicians, government attorneys, and combatants. ${ }^{7}$ Both politicians and combatants are decision-making actors in relation to engagement in or refraining from battle. In this sense, an imposition of liability, either directly on them or vicariously on the state, might, in theory, deter them from engaging in certain activities. In addition, government attorneys are relevant actors both because they advise politicians and combatants about the possible legal ramifications of their conduct, and as government attorneys can be an integral part of the legislative processes that determines who is liable in tort. ${ }^{8}$ The key question is, therefore, whether these three groups of actors could be overdeterred from engaging in combatant activities when tortious liability could be imposed.

To this end, it is essential to understand what I refer to as 'the spectrum of deterrence'. Deterrence is commonly understood as the potential of tort liability to influence an actor's decision whether to engage in a potentially injurious activity or how to conduct it considering the pecuniary costs and benefits that are associated with the various choices she has. Under-deterrence is at one end of the spectrum, and it occurs when tort liability does not incentivize individuals to take due care. Over-deterrence is at the other end of the spectrum, and it occurs when tort liability provides incentives so strong that individuals might avoid taking action even when they will not result in a wrong for which they will be held liable. Somewhere in between lies the optimal level of deterrence, which prompts individuals to act with an adequate degree of care. ${ }^{9}$

This understanding of deterrence is premised on three assumptions. First, that individuals have a choice whether to participate in or refrain from an activity, and from taking precautions in relation to that activity (Jacob 2003, 127). Otherwise, tort liability is not likely to influence their 
behavior to a significant extent as they must act, or refrain from acting, in the particular way that is prescribed to them. Second, it is assumed that individuals have accurate information about the costs and benefits that are associated with action and inaction, and an opportunity to engage in a rational analysis of this information. ${ }^{10}$ Partial information and lack of expertise in analyzing its meaning result in erroneous determinations, which in turn could provide misguided ex ante incentives to individuals (Goldberg 2003, 552). Third, it is also assumed that an imposition of liability will, generally, change individuals' balance of reasons thus incentivizing them to act more carefully, and that without this incentive individuals will not act with due care (Sugerman 1989, 12-18). In the context of belligerent activities, each of these preconditions does not seem to be met in relation to the three relevant actors during warfare.

The ability to choose freely between courses of action is somewhat limited in combat. When politicians are in the position of directing the military's activities, they are free to choose whether the military will engage in combat. Indeed, they can opt for a completely pacifistic approach to any threat their country and constituents face. Yet, it is equally possible that politicians will prefer to incur the financial costs that arise from engaging in battle over the political or financial costs of inaction, even if the former is greater than the latter. ${ }^{11}$ Politicians' discretion, in this regard, is wide. That said, politicians might not have the knowledge or willingness to choose the exact course of action and defer on this issue to high-ranking combatants.

Combatants' discretion is significantly more limited. Once politicians have ordered them to engage in a belligerent activity or refrain from it, they have little choice over the matter. Highranking combatants might have the ability to choose how and when to engage in the belligerent activity, but this expression of a choice is more limited, by and large, when it comes to lowerranking combatants. Most commands are given to lower-ranking combatants with a high degree 
of specificity and a low degree of discretion. Furthermore, when faced with risk to themselves or others, combatants might feel obligated to act in self-defense (Benbenisty, Ben-Shalom, and Ronel 2010, 42), lack the time to make cost-benefit considerations, or that they might be forced to act inadvertently. ${ }^{12}$ In either case, it is hard to see how liability could have any deterrent effect as freedom of choice is very limited (Jacob 2003, 128; Englard 1993, 43-44). Additionally, while they can refuse to participate in belligerent activities, and perhaps from enlisting altogether, in doing so they are accepting the possibility that they could be held criminally or administratively liable.

Likewise, government attorneys' discretion is limited. They can advise politicians and combatants on the legal nature and implications that certain acts or omissions might have. In doing so, they cannot offer legal advice that is beyond the scope of their role, and they are generally not in a position to order that a combatant activity be conducted or not. Rather, they advise the individuals who will decide whether to engage in combatant activities.

As for information about the various costs and benefits of combatant activities, it seems that all three groups of actors are unlikely to have a full and accurate account. War is known to be "the realm of uncertainty" (Clausewitz 1832, 101). Any analysis could not be made with certainty, or even a high degree of plausibility, and it is unclear whether the lack of information will result in over- or under-deterrence. The degree of deterrence that an imposition of liability would add in this calculation hinges on the level of risk-aversiveness of each group of actors, the weight they assign to tort liability considerations, and their ability to freely choose their course of action. Furthermore, while politicians, government attorneys and high-ranking combatants might have more information regarding the various costs and benefits of each particular activity, as they might have access to such information, lower-ranking combatants are less likely to have it. Lower- 
ranking combatants might be informed about what costs and benefits their mission generally entails once it has been decided, but they will not be informed of various alternatives to their mission.

Lastly, all three groups of actors are unlikely to bear any of the costs personally for three main reasons. First, potential plaintiffs are discourage from filing claims due to high litigation costs, low potential compensation, and procedural hurdles (Bachar 2017, 849-51). With fewer plaintiffs standing on their rights, neither individual state agents nor the state fully internalize the costs of the losses it inflicts (Schwartz 2002, 1071). Second, in those instances that plaintiffs do decide to sue, it is the state and not any particular agent of it that is sued. The motivation could be the unknown identity of the combatant who actually inflicted the loss, the fact that the state has deep pockets from which plaintiffs can recover their costs (J. M. Jacob 1992, 455; Crootof 2016, 1390), or a legal hurdle to holding a public official liable. ${ }^{13}$ Third, even if individual agents were sued, the state could not only be held directly or vicariously liable, but also it might pay the cost of compensation in its agents' stead. ${ }^{14}$ The combination of these three factors result in little to no internalization of costs by individual state agents from any of the three relevant groups. Moreover, the state is likely to be indifferent to the costs of tort liability, as such liability is unlikely to have a significant budgetary implication on it.

Consequently, it seems that politicians, combatants, and government attorneys are unlikely to be deterred by a potential imposition of tort liability. While politicians have relatively more freedom to choose their course of action, combatants and government attorneys are more restricted in what they can and cannot do, especially while belligerent activities are being conducted. Information for all groups is partial, and lower-ranking combatants are generally likely to have the least amount of information regarding the costs and benefits that are associated with various forms 
of action and inaction available to them. Individuals from all groups of actors will not internalize the costs of losses they impose, and the State's budget will not be affected in any significant way from an imposition of tort liability. Given that all three preconditions are not met by any particular group of state actors, it is hard to maintain that tort liability in this context will have an overdeterring effect, ${ }^{15}$ deterrence in this context seems theoretically unlikely.

\section{TESTING THE THEORY}

The purpose of this empirical study is to test the theoretical conclusion I reached above, namely that politicians, combatants, and government attorneys are not likely to be over-deterred by the notion of an imposition of tortious liability for losses that are inflicted during battle. This hypothesis is based on two assumptions. First, many actors do not possess information about the potential risk that is associated with an imposition of tort liability, and so the idea of liability could not deter them. Second, even those actors who do have the required information to potentially be deterred would nevertheless be risk-neutral in relation to tort liability, either as liability considerations would have little to no weight in comparison to security considerations, or as those actors would not have a choice regarding whether or how to engage in belligerent activities.

That said, it is important to note that as an exploratory study, its findings are suggestive of the possible deterrence effects of tort law on state actors in relation to combatant activities. However, the study was not designed to prove causality in the local Israeli test-case or universally, and other factors might also influence state actors' decision to engage in or refrain from belligerent activities. $^{16}$

\section{Data and Methods}




\section{Survey}

I conducted an online survey that was aimed at assessing whether combatants could be deterred from engaging in belligerent activities due to tort litigation and liability. The survey was administered on May 7, 2018, and was open until July 2, 2018, to individuals who identified as Israeli combatants on active or reserve duty. ${ }^{17}$ The survey had three parts, and the questions were primarily close-ended. There were two versions to the survey to control for question order bias. In one version, respondents were first presented with three vignettes, then in the second part they were asked additional questions, and in the third part demographic information was solicited. In the second version, the order of the first and second parts was reversed, and the order of the questions in the second part was altered.

I distributed my survey through social media. I shared a link to the survey through Facebook, LinkedIn, WhatsApp, and Telegram, in my public profile, and in groups dedicated to mutual assistance or military service. The link was subsequently shared by followers and other users. I also directly contacted individuals on Instagram, whom I identified as combatants through their tags. ${ }^{18}$ I chose this method of distribution as no other viable alternative exists for this specific study. There was no survey service that can slice the population according to the type of military service, and collaborating with the IDF was ruled out as the results of such collaboration would not be allowed to be made public.

I solicited demographic information in the third part of the survey. The sample includes 320 individuals in total, of which some chose to disclose their demographic information. 192 identified as male, 14 identified as female, all between the ages of 18-45. 88 respondents identified as serving in active duty, while 114 identified as serving in reserve duty. Ranks varied from Private to Major. 86 identified as single, 60 identified as being in a relationship, and 58 identified as having 
children. 106 identified as having participated in combatant activities in the past, and 97 indicated they did not. Lastly, 71 individuals identified as left-wing (response on scale of $0-100 \leq 50$ ) and 112 as right-wing (response on scale of $0-100 \geq 51$ ). The demographics indicate that the survey was distributed to a diverse audience along some axes, such as age, active or reserve service, and political view, thus the risk of sample bias was reduced. Still, some risks remain as the demographic indicators are self-reported and the lack of diversity along some of the axes. Given these limitations, as well as the aim of this paper to offer an initial, yet rich and insightful, exploration of combatants' attitudes towards tort liability, it is important to note that I am not claiming that the sample is representative or that the results uncover an objective "truth".

The three vignettes presented the respondents with hypothetical scenarios in which they must decide whether to engage in potentially tortious behavior with a backdrop of particular legal rules or conditions. This method was chosen as the existing immunity from liability makes an accurate assessment of the levels of deterrence that liability could generate difficult without relying on an analysis of hypothetical scenarios. In each of the three vignette respondents were informed that if civilians were hurt or killed while engaging in a combatant activity, an Israeli court will declare that they will be compensated. The first vignette did not specify the amount of compensation, the second vignette specified the amount to be 500 ILS, and the third vignette specified the amount to be 5 million ILS (equivalent to roughly 150 and 1.5 million USD). Furthermore, the respondents were informed that the risk faced from the target of the combatant activity is low. They were then asked to indicate how likely are they to attempt to avoid engaging in the combatant activity in four alternatives:

1) The court will instruct the state to compensate its own civilians

2) The court will instruct the state to compensate enemy civilians 
3) The court will instruct them to compensate fellow civilians

4) The court will instruct them to compensate enemy civilians

The likelihood was measured on a sliding scale, anchored at the low end (0) by "I will not attempt to avoid engaging in the combatant activity at all", and at the high end (100) by "I will do everything in my power to avoid engaging in the combatant activity."

In the second part of the survey, respondents were asked seven short questions. Two questions were aimed at gauging the degree to which combatants believe they have the ability to choose their course of action freely: one when they were instructed to strike a target during a briefing, and the other when such instruction was given in the theater of operations. They were asked to choose between three options:

1) They have the ability to choose whether to engage in a combatant activity or refrain from doing so.

2) They do what their commanders order them to do.

3) They do what other combatants do.

Respondents were also asked to indicate whether the statement that the state can be held liable in case civilians are injured during belligerent activities is true or false, and whether such a statement is true or false in regard to the possibility that they will be held liable under such circumstances. Lastly, respondents were asked to indicate, using a 5-point Likert scale (anchored at the low end (1) by "I completely disagree with the statement", and at the high end (5) by "I completely agree with the statement"), if they would prefer to avoid participating in a combatant activity if:

1) They would have to testify about the activity in an Israeli court;

2) Other people would claim that their actions were immoral or illegal; or

3) If participating in the combatant activity would result in their inability to travel to 
various countries.

\section{Semi-Structured Interviews and Secondary Sources}

I conducted interviews with 13 individuals in total, who are high-ranking officers, politicians, legal counsels, or district and state attorneys. The interviews were conducted in Hebrew in January and February 2019, both online and in person, lasting between 30 minutes to two hours. All but two interviewees consented for the interviews to be recorded and transcribed, and that detailed notes will be taken. Six interviewees asked to remain anonymous. These include members of the legal community who are involved in tort litigation against the MoD, which is small and close-knit. Hence, I will refer to district and state attorneys, and Ministry of Justice legal advisors, as 'government attorneys' ("GA") to maintain confidentiality. In addition, interviewees who are highranking officers in the IDF who wished to remain anonymous will be referred to by rank and 'IDF'. All other interviewees have agreed to be attributed. I transcribed the interviews manually and translated them into English.

To identify possible relevant interviewees, I began by examining the combatant activities exception legislative history. There are 16 protocols in total that are relevant for the legislative process of the combatant activities exception, from its initial enactment to its most recent amendment. However, in only 11 of these protocols there is meaningful discussion that could be used to evaluate how actors perceive the notion of an imposition of tort liability for combatant activities. Ten of the relevant protocols are from the Knesset Constitution, Law, and Justice Committee, and one is from the Knesset Plenum. Also, there are explanatory notes attached to the four relevant Bills introducing the exception or its amendments. A total of 171 individuals took part in the deliberations, of which 50 were politicians, 15 military personnel, 42 government 
attorneys, and 64 individuals with other affiliations. I then reviewed these results to locate key stakeholders through the office they held and the number of appearances of their names in the secondary sources. The resulting list included 24 politicians, 11 military personnel, and 17 government attorneys. Interviews were secured first by contacting individuals that belonged to the three relevant groups of state actors when their contact information was publicly available from Google and the Israel Bar Lawyers Database (N=25). Response rate was 24 per cent. Subsequent interviews with key stakeholders, who have expertise and intimate knowledge on the factors that influence the relevant state actors in deciding whether and how to engage in warfare or the amendments to the combatant activities exception, were secured through a snowball process.

It should be noted that interviewees' accounts are susceptible to a variety of factors, such as selective recollection of past events, a concern with confidentiality, self-interest, and selfaggrandization. My analysis proceeded with these factors in mind, contrasting and comparing the accounts of my various interviewees with each other, as well as with recorded evidence of past events in the secondary sources I examined. In this sense, I do not perceive my interviewees' accounts as representations of truth per se, nor are they treated as a source through which an objective representation of reality or intention can be derived from. Rather, attention is given to the language, perspectives, and narratives that arise from their accounts of the law and its development (Ewick and Silbey, 29; Geva, 707).

Furthermore, I assessed additional secondary sources and relied on the findings of an empirical study of 1,486 combatants, that was conducted by the IDF in 2009 after operation 'Cast Lead', and was aimed at identifying what factors motivate soldiers to engage in combat (Benbenisty, Ben-Shalom, and Ronel 2010, 42). 869 combatants were in active duty, 569 were in reserve duty, and 21 did not specify the type of their service. 
Using qualitative content analysis, I coded and analyzed the interviews' transcripts and secondary sources, taking an inductive and a contextual interpretive approach. This process enabled me to identify three themes of motivations for enacting and amending the combatant activities exception and for engaging in warfare by the three relevant groups of actors. First, protecting security interests initially prompted politicians to enact the exception to avoid deterring combatants from doing all that needs to be done to achieve military aims. However, tort law-related considerations were entirely abandoned from decision-making processes soon thereafter. Second, promoting legal coherence and capabilities, which views the conditions of warfare as intrinsically incompatible with the underlying character of tort law. Third, entrenching a political stand that the enemy population should not have access to remedies that indicate that Israel acted wrongfully.

\section{Security Interests Are A Cardinal Consideration}

When Israel was established in 1948, the state enjoyed blanket immunity from tortious liability for its actions, following an Ordinance from the British Mandate that remained in force. However, in 1951 deliberations regarding the abolishment of this blanket immunity regime began. These deliberations provide some insights into the motivations that politicians had for enacting the combatant activities exception. One such motivation was the fear that the possibility of an imposition of tort liability for losses that are inflicted during battle would over-deter combatants from doing all that needs to be done to attain military goals. For instance, Member of the Knesset ("MK") Jacob Shapira stated that:

The State's security interests necessitate that during belligerent activities combatants' hands shall not be tied by potential compensation that will be 
required, but that their thoughts would be solely focused on those actions that are essential for the protection of the state (Protocol 49).

Similarly, MK Ami Assaf stated that:

If the definition of combatant activity will have nuances it can lead to a limitless burden...In this matter we cannot be too meticulous, as due to my conscientious deliberations the military's necessary freedom of operation could be harmed (Id.).

It is therefore no surprise that when the Bill which abolished Israel's blanket tort immunity passed in 1952, it included a combatant activities exception. Section 5 of the Civil Wrongs (State Liability) Act stated that Israel is not "liable in tort for a combatant activity committed by the Israel Defense Forces." However, apart from this mention of tort liability as a possible deterrent to warfare during the deliberations that resulted in the 1952 Act, no such consideration was expressed in any other secondary source or interview.

In fact, the concern for security interests seems to outweigh considerations of tort liability in relation to decisions on if and how to engage in belligerent activities. Many interviewees emphasized that greater value is placed on achieving military goals and eliminating security risks over financial considerations, both generally and in relation to potential tort liability in particular. For instance, Colonel Prof. Gabi Siboni, who served as a fighter, commander, and as the chief of staff of the Golani Brigade, stated:

Considerations of compensation do not influence the decision to go on a mission. But maybe that is too strong of a statement. On the political level the need to compensate is accounted for. We do not take over the Gaza Strip because that 
will cost a lot of money. But that is not accounted for on the operational level.

Similarly, MK Deputy Commissioner David Tsur, who was a member of the Knesset, Head of Israel's Counter Terrorism Unit, Head of Israel Border Police (a body that is composed of both police and military forces and operates in the occupied Palestinian territory), and participated in numerous cabinet deliberations in which police and military operations were discussed, commented that:

In Cabinet meetings the security consideration is always very important... and it is a decisive factor...[Damage to] infrastructure and other things of the sort are not considered as much when fighting terrorism as this type of losses are restorable... The main value that is being contemplated is human life, and the lives of the combatants and civilians...THE consideration is neutralizing the threat...the financial consideration is less concerning at the operational level.

Even more explicitly, MK Major General IDF2 replied when asked whether politicians consider the costs of tort liability when they determine if to order an engagement in a combat that "in my time it was not a consideration. There are many heavy considerations, and this is not one of them!" 19 Likewise, Major General IDF3 stated: "No one thinks in these terms in the military, and rightly so."

Put differently, when state actors were concerned about the possibility of an imposition of tort liability, they thought about liability as a security risk, hindering combatants from properly engaging in warfare. However, tort liability no longer seems to be a concern for state actors in this sense, nor does it appear to be a factor that is accounted for when deciding whether and how to conduct belligerent activities. 
In fact, financial considerations seem to play little to no part in these decisions, and combatants appear to have little knowledge about potential tort liability risks that can be imposed on them or the state due to their conduct. Accurate knowledge of the possibility of incurring costs due to tort liability would reflect that neither the state nor combatants can be held liable. ${ }^{20}$ Yet, the results of the survey I conducted indicate that most combatants' knowledge of potential tort liability is not entirely accurate. $68 \%$ of combatants held the erroneous belief that the state might be held liable, and $10 \%$ of combatants incorrectly believed that they might be liable. These finding support the assertion made by government attorney GA2, who noted that "non-lawyers do not know the case law. It is not their job. Only in exceptional cases, like Elor Azaria [a combatant who committed an extra-judicial killing of a neutralized terrorist] officers know court rulings" (Interview, GA2).

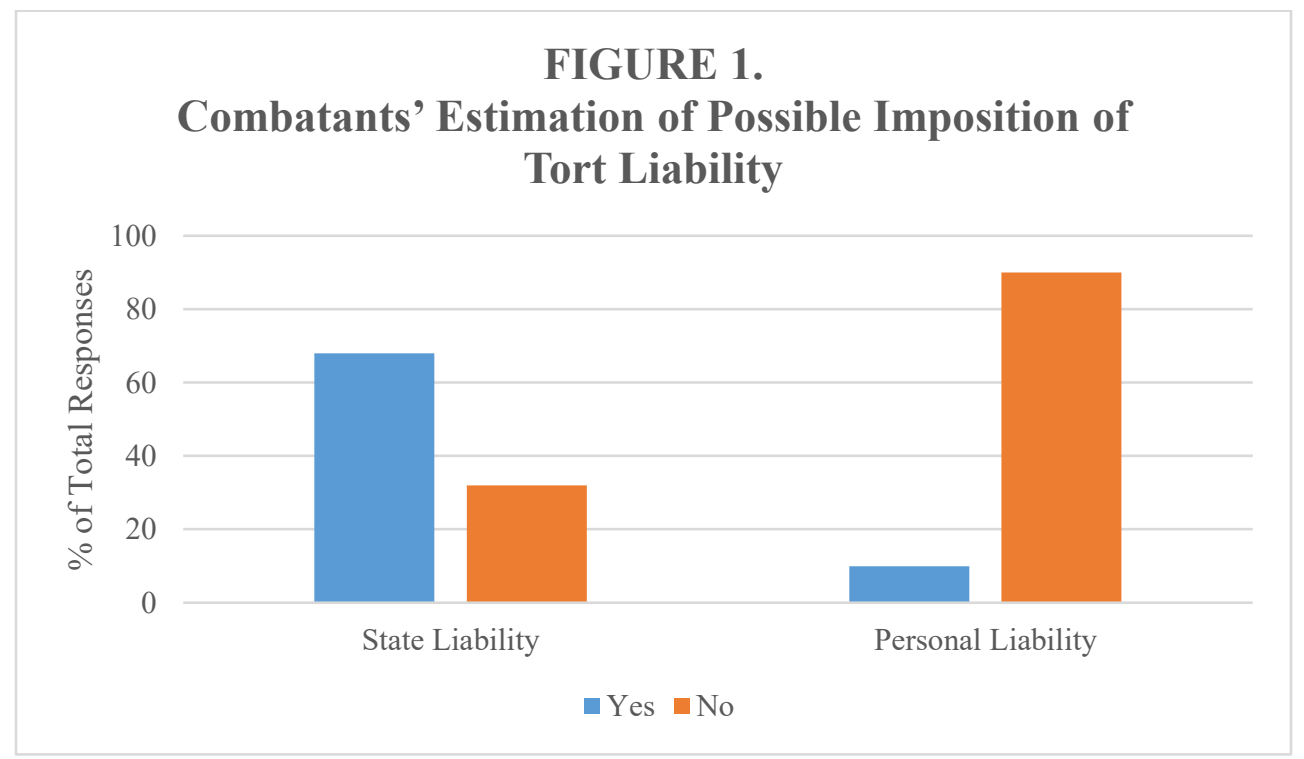

NoTE: $\mathrm{N}=277$

This is not to say that financial considerations have no influence whatsoever. The State's 
"deep pockets" simply mean that these considerations can always be accounted for and their potential impact can be circumvented. Consequently, it seems that there will never be a situation in which the military will not be able to engage in belligerent activities due to an imposition of tort liability. Brigadier General Dr. Sasson Hadad, who served as the Financial Advisor to the IDF Chief of Staff and was Head of the Budget Division of the Ministry of Defense, assisted in shedding light on this very point:

Our goal as financial advisors is to have the IDF units conduct themselves in an optimal fashion... There was never a case that a unit was incapacitated by liability...The economic approach is aimed at assisting, not paralyzing the operational level (Interview with Brigadier General Sasson Hadad).

Advocate Ahaz Ben Ari, who served as the Chief Legal Advisor to the MoD, Assistant Military Advocate General on International Law, and the Legal Advisor to the Gaza Strip and West Bank, voiced a similar position:

In the $\mathrm{MoD}$, every year in preparation for the fiscal year, a survey is made for [the] accounting [department] of all of the pending cases and the financial risk they entail so we can put the required funds aside...There is no situation in which there will be a ruling against us and accounting will say 'but we don't have a way of paying it' because there will always, somehow, be a way of paying it...I don't remember an instance in which I told the military 'don't do this or that because it already costed us once'...The budgetary issue should not raise any concerns. The budget line that is set aside for tort cases is acting like auto-pilot... If a survey says that this year is going to be very difficult with enormous sums, 
we think where we'll bring the funds from in advance so that there wouldn't be a problem later (Interview with Advocate Ahaz Ben Ari).

The costs of tort liability, therefore, seem to be an integral part of the costs of engaging in military operations. Tort liability is not an unexpected expenditure, nor is it an impediment to the State's actions. In this sense, some of the force of an imposition of tort liability as an incentive to act more carefully is diluted, as pecuniary costs do not require the State or its actors to review their actions for fear of inability to conduct similar activities in the future. Nor is any particular imposition of liability an extraordinary occurrence that requires attention. Rather, tort liability is considered part of the ordinary operations.

At this stage, it could be argued that these findings mostly reflect the current legal reality, in which both the state and its combatants are immune from liability. To assess whether the fears politicians expressed in 1952 of tort liability deterring combatants from engaging in warfare could have a hold in practice, I presented survey participants with three hypothetical scenarios. As is illustrated in Figure 2, combatants' level of deterrence varied according to the different hypothetical factual scenarios presented to them. When the state was said to be held liable for its own civilians, combatants reported that their level of deterrence is less than $40 \%$. However, when the state was said to be liable for enemy civilians, combatants reported a level of deterrence of less than $48 \%$. In contrast, when liability was said to be borne by the combatants themselves, deterrence level was reported to be less than $72 \%$ whether liability was to their fellow civilians or to enemy civilians. 


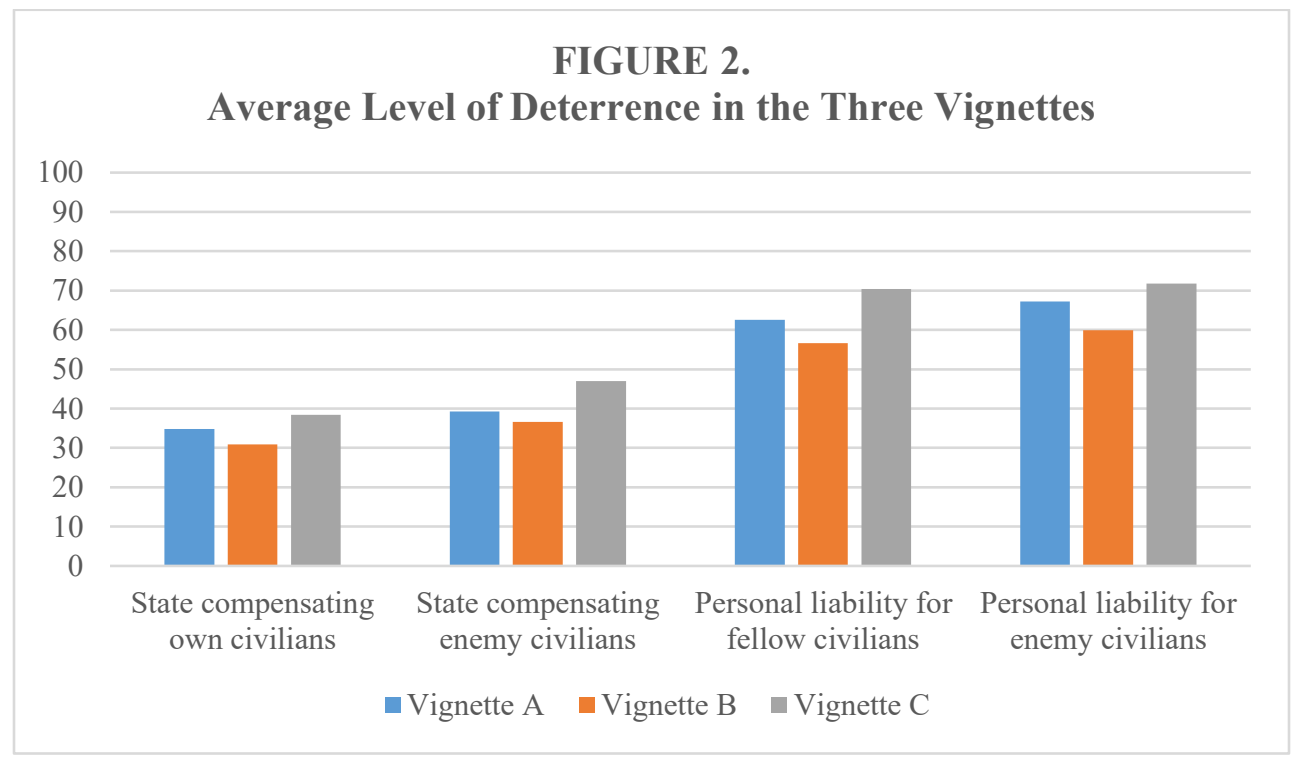

NOTE: $\mathrm{N}_{\mathrm{A}}=287 ; \mathrm{N}_{\mathrm{B}}=233, \mathrm{~N}_{\mathrm{C}}=217$. Level of deterrence measured on a -100 scale.

At first glance, these results seem puzzling and counterintuitive. The theoretical analysis of deterrence suggests that combatants would be entirely indifferent to an imposition of liability on the state, as they do not internalize its costs. The theoretical analysis also suggests that combatants should be entirely deterred when liability could be imposed on them. Yet, the survey responses did not align with this analysis. Instead, respondents were somewhat deterred by an imposition of liability on the state and somewhat more deterred when liability could be imposed on themselves.

This puzzling result is clarified when two factors are considered. First, the degree of care for and identification with the State that combatants have. I will return to this point later in my analysis. Second, combatants' ability to choose if and how to engage in belligerent activities. In the survey, most respondents replied that they did not believe they are free to choose their course of action. As indicated in Figure 3, they either do what their commanders order them to do, or they follow what their fellow combatants are doing. Only $19 \%$ of combatants indicated that they have 
freedom of choice whether to engage in or refrain from a combatant activity during a pre-operation briefing, and in the battlefield this number was reduced to $17 \%$.

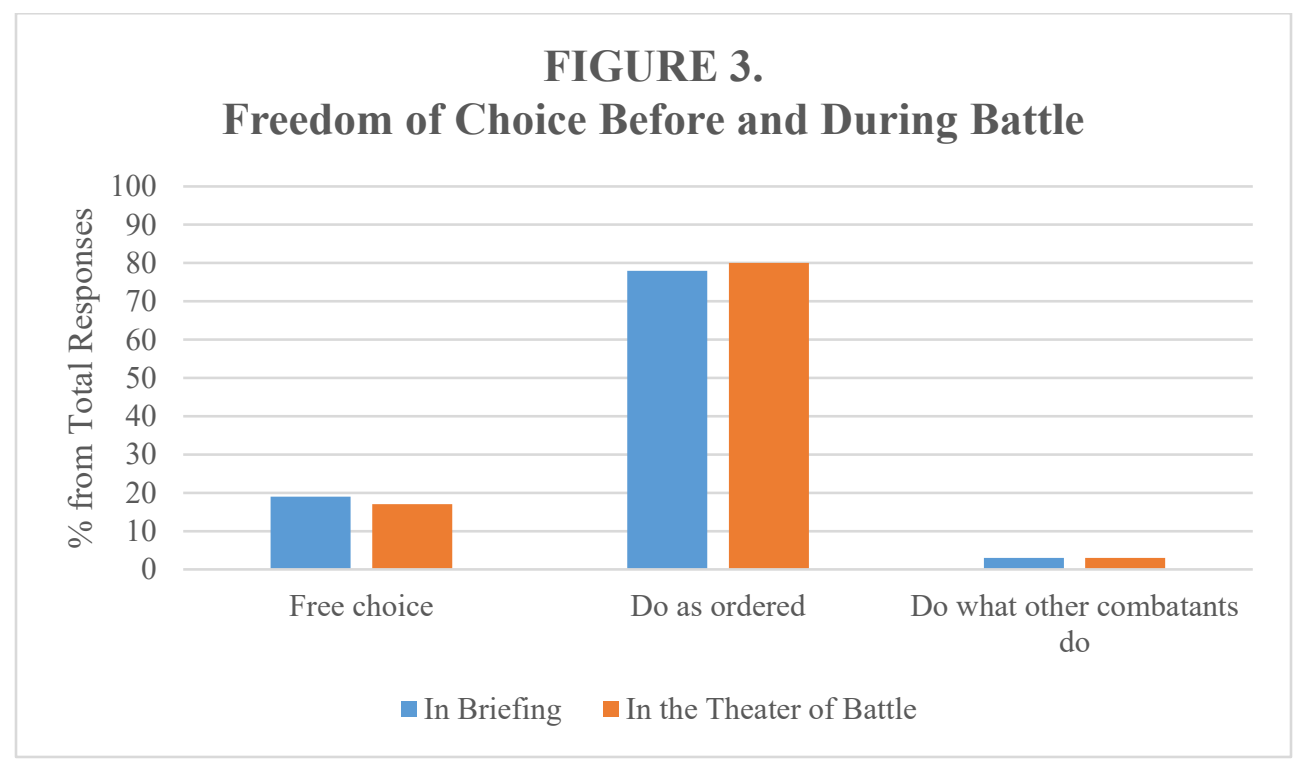

NoTE: $\mathrm{N}=277$.

These results are supported by an analysis of the interviews I conducted. For example, Colonel Prof. Siboni explains: "In the military there is a command. There is no choice whether to execute...Assuming the command is legal there are no subsequent degrees offreedom. At the end of the day a command must be performed." MK Deputy Commissioner Tsur offers a more nuanced account:

On the strategic level there is complete freedom in the Cabinet. The political ranks decide on the 'what', but on the tactical level...the degree to which the political ranks weigh in depends on the people... The tactical ranks decide on the 'how'...Lower ranking combatants have the ability to weigh in [on the 'how'] 
in certain cases, depending on the type of the unit and whether their input is relevant. During combatant activities there is freedom to act within set guidelines.

Lacking the ability to choose if and how to engage in belligerent activities means that combatants' personal considerations regarding tort liability play little role in how they will behave on the battlefield. The hypothetical presented to combatants asked them to indicate their level of deterrence in relation to each scenario on a sliding scale, anchored at the high end by "I will do everything in my power to avoid engaging in the combatant activity." It may very well be that in the context of a hierarchal command structure, lack of choice means that even though combatants might be deterred by the idea of engaging in belligerent activities, they do not have the power to avoid participating in them. Alternatively, it may be that on the balance of reasons, the level of deterrence from tort liability is not enough to incentivize combatants to act in a particular way or to refrain from acting altogether.

While tort liability seems to have weak to no impact on decisions on whether and how to engage in warfare, the laws of war seem to be a relevant factor that is accounted for by state actors in this context. These laws prescribe which instances of use of force are legitimate and which are prohibited. Any command that violates the laws of war is illegal, and its execution should be refused. Basic training and guidance on the laws of war is provided to every soldier, and military lawyers advise commanders on the legality of combatant activities. MK Deputy Commissioner Tsur stated that

The State Attorney can say that something doesn't work with the rules of international humanitarian law and so we don't go ahead with a combatant 
activity...compliance with international law is the most important thing in this regard...There are legal advisors in almost all operational decisions...but they inform on how to do things that will "pass" legally, and they rarely hinder them (Interview with MK Deputy Commissioner David Tsur).

These observations align with findings which indicate that from the second Palestinian uprising ("Intifada") in the early 2000s, military attorneys began viewing their role as facilitators of use of armed force rather than technicians of the laws of war or impediments to abuse of force (Geva 2019, 708-16). As one senior official in the International Law Department of the Military Advocate General Corps stated: "Our goal is not to tie down the military, but to give it the tools to win in a way that is legal" (Blau and Feldman 2009). This point was also made by Colonel Pnina Sharvit-Baruch, former head of the International Law Department: "I am there to find legal ways to achieve the goals of the army. ... I am not there only to say what they can't do. I am also there to say what they can do and how to do what they want to do in a legal way. This does not mean that I will tell them how to do something unlawful' (Craig 2013, 185).

This shift in perspective coincided with a change in the way military lawyers understood the character of the functions the military was doing in the Gaza Strip and the West Bank. They no longer thought about these activities as policing, but as actual combat that is short of full war (Geva 2019, 715-16). Additionally, such factors as knowledgeability about the law, battlefield experience, and cultural background can also influence the way in which the laws of war are understood, interpreted, and applied (Statman et al. 2020, 450-51).

That said, the ability of government attorneys to influence whether and how combatant activities are pursued is somewhat limited. They can inform politicians and combatants about the degree to which particular belligerent activities would adhere to or be a breach of international 
humanitarian law, and the possible tort liability that might follow. Yet, government attorneys do not have the power to order that a particular combatant activity will be pursued or stayed, and tort liability is not a factor that is presented to politicians and combatants when contemplating these matters.

We can see that the laws of war are a consideration that is taken into account by the relevant state actors, but security interests influence the way in which they are interpreted and applied. Furthermore, tort liability was considered as a factor that might influence the decision on whether and how to engage in combat only once briefly in the history of the State of Israel and is no longer viewed as a relevant factor in this context. As such, security interests seem to have greater weight than other considerations that were mentioned in the interviews and secondary sources.

\section{Legal Coherence and Viability}

The 1952 iteration of the combatant activities exception simply stated that Israel is not "liable in tort for a combatant activity committed by the Israel Defense Forces." This definition of the exception did not specify what amounts to a 'combatant activity', and consequently two approaches emerged in courts' rulings: one interpreted the exception narrowly, and the other interpreted it broadly.

According to the narrow approach, a combatant activity is one which is only conducted during warfare, and which bears "familiar signs of combat, or if the action is one that is ordinarily performed in the midst of war" (Mifal Takhanot Hatraktorim Ltd. v. Hayat, 1613). Similarly, in the 1986 Supreme Court case of Levi, Justice Shamgar held that only "actual combatant activities in their narrow and simple sense... are the ones to which the language of section 5 relates to" (Levi v. Israel, 479). In another key case, the Jerusalem Magistrate Court held that one of the 
characteristics of a combatant activity is that it is rare and abnormal. Hence, actions in which a military force encounters violent protesters, which became routine during the first Intifada from 1987 to 1993 , should not be understood as combatant activities, but rather as policing activities (Abu Jabar v. Israel, 19).

In contrast, the broad interpretation applied the exception to negligent activities even when there was no objective and immediate risk to combatants (Atallah v. Israel, 554), and most significantly to policing activities in the Occupied Territories - deeming them as combatant activities (Abu Shamisa v Judea and Sameriya Military Commander, 9). It is this latter aspect that was the key point on which the two interpretive approaches disagreed on.

At the end of the 1990s, government attorneys began working on legislative amendments to expand the scope of the exception. The main purpose of Amendment 4 was to include policing activities in the Occupied Territories under the definition of 'combatant activities' (Draft Bill 2645 for the Treatment of Claims Against the Security Forces; Protocol 405).

However, these attempts did not bear fruit until the first in-depth analysis of the combatant activities exception, and its applicability in situations involving policing activities, by Israel's Supreme Court in the 2002 Bani Uda case. ${ }^{21}$ In this case, Justice Barak held that ordinary tort law is not suited to deal with the special risks involved in warfare (Jamal Kasam Bani Uda v. Israel, 7). ${ }^{22}$ Adopting the narrow approach, Justice Barak held that determining the applicability of the exception requires examining the specific injurious action, rather than the overall operations, bringing under its scope only actual belligerent activities in their simple and narrow sense. ${ }^{23}$

The legislature was quick to embrace Justice Barak's reasoning to push the amendment of the Act forward, successfully passing it only five months after the Bani Uda decision was given. Yet, while Justice Barak's ratio of the inapplicability of tort liability to warfare was adopted, the 
narrow approach to the exception was forsaken in favor of a broad approach to it, including more activities that are not strictly 'combatant' as falling under the combatant activities exception. Since then, government attorneys initiated two additional amendments - the 2005 Amendment 7 and the 2012 Amendment 8 - with a similar aim of expanding the exception. These amendments extended immunity for counter-terrorism activities in circumstances that would fall outside what would be deemed as 'combatant activities' according to the Bani Uda precedent.

All amendments seem to have been prompted by the fact that the state was dealing with thousands of tort cases against it due to the operations of its security forces in the Gaza Strip and the West Bank following the first and second Palestinian uprisings. One government attorney said during an interview I conducted that "until 2013 there were thousands of open cases, and today there are a few dozens a year - if any. Dealing with these cases was very difficult...The ability to locate evidence and witnesses was extremely problematic" (Interview, GA1). ${ }^{24}$ Another noted that "there was a flood of hundreds and thousands of cases a year, and that was a part of the incentive to expand the combatant activities [exception]" (Interview, GA2). A third stated that

What led to the amendments - the crazy flooding [of cases] and the disengagement [from the Gaza Strip]...Before [the amendments], every operation...resulted in a flood of lawsuits...We're talking about a lot of cases, a lot of state attorneys, a lot of meetings, a lot of procedures, for not a lot of compensation. It is a lot of noise...that has a burdening effect that jams the system (Interview, GA3).

Yet, it was not simply the "noise" these tort cases were producing that prompted government attorneys into action. Rather, it was also the fact that they were losing cases. The culprit was 
identified in the Constitution, Law, and Justice Committee deliberations regarding the various amendments of the Act as evidential difficulties government attorneys faced when they argued that the exception should be applied in courts. Ascertaining whether the plaintiff was hurt by Israeli forces, and the extent of the injuries, was a challenging task considering the fact that, by and large, the plaintiffs reside in hostile territories (Protocol 66). Furthermore, even when the information regarding the nature of the operation was obtainable, the government attorneys' position was that there is still an evidential difficulty as this information is often confidential. In these situations, the state faced one of two scenarios. Either it had to expose confidential information, or it had to settle in order to keep the information out of the public's eye. District Attorney Irit Kalman Describes this very dilemma:

A taxi was driving towards a roadblock with a suicide terrorist who carried a bomb. Intelligence was received regarding the taxi and the immanent terror attack...Without the use of targeted killing on the taxi the terror attack would have been executed. The taxi owner filed a claim... We came to the courts with affidavits from Brigadier Generals with all the information we could divulge...The court wanted to know who we got the information from, maybe it is wrong, maybe we were misled... In this case we were not misled but we cannot bring the evidence to court (Protocol 489).

Government attorneys' problem with the evidential difficulties they faced in this context was more than merely frustration with lacking all the resources they need to properly defend their position. Rather, they believed that by expanding the scope of the exception, and hence reducing or eliminating Israel's tort liability for losses its security forces inflict, they are codifying a 
principle. Advocate Tamar Kalhoora, the representative of the Counseling and Legislation Department of the Ministry of Justice, ${ }^{25}$ stated that "the purpose of this Bill is...to ground the idea that in war or armed conflict...every side needs to shoulder its own losses"” ( Protocol 81; Protocol 502). Likewise, government attorney GA2 said that:

The choice to call it the combatant activities exception - in my view it is not an exception...Violent conflicts or actual combat activities...don't have a solution in the realm of tort cases because the situation is less under control for all the parties involved - the heat of battle and all that. All of the relationships we are used to talk about between wrongdoer and injured individual, and all the elements of negligence...they probably don't exist. (Interview, GA2).

Advocate Ahaz Ben Ari also noted in this context that government attorneys were simply trying to adapt the exception to the changing nature of warfare:

We expanded the definition of combatant activity to include counter terrorism activities...so that courts will have no doubts on this matter, because sometimes there was uncertainty regarding whether an action should be classified as 'policing' or 'combat'. In this sense, the state has total immunity.

When asked why it was the government attorneys who initiated the amendments, rather than combatants or politicians, interviewees replied that it is due to the fact that the government attorneys have the accumulated knowledge that is required to identify the difficulties that they believe require legislative reforms. As advocate Ben Ari described it: "the legal departments of government offices become an information gathering hub, that allows them to see all sorts of phenomena that occur through tort cases" (Interview with Advocate Ahaz Ben Ari). 
Yet, it is important to note that interviewees have indicated that while every case is tracked, there is no formal institutional mechanism of review through which the results of each case are studied. In government attorney GA1's words: "the system is not built to review cases, and there is a big workload that doesn't allow such processes to occur." Rather, there are informal social information networks, that could be broadly classified into three categories. First, there is a Tort Law Forum, in which representatives from the district and state attorney offices (and sometimes legal counsels from ministries as well) gather every few months to discuss cases that the state is a party to and broader issues they identify that arise from them (Interview, GA1; Interview, GA2; Interview, GA3). Second, there are state-wide and district specific email chains for the state and district attorneys to report on, and ask questions regarding, their cases (Interview, GA2). Third, knowledge is transmitted through what government attorney GA2 referred to as "war stories", but could also be aptly described as hallway chatter.

\section{Limiting "the Enemy's" Access to Court}

The efforts to amend the combatant activities exception, so that it would better reflect what government attorneys believed to be a more accurate reality of contemporary warfare and tort law, were not merely out of a concern with theoretical purity and coherence. Nor were the amendments driven solely by procedural difficulties the state faced when defending itself from tort claims. Rather, the identity of the individuals bringing tort claims and their perceived motives for doing so played a role.

Between 1988 and 2014, Israel paid approximately 305 million ILS (equivalent to roughly 94 million USD) in compensation for losses inflicted by its security forces on the Palestinian population in the West Bank and Gaza Strip, either as it was held liable by courts or due to 
settlement agreements (Lev 2015). For some, the fact that these payments were made justified expanding the exception. It seems that many of the relevant state actors began to perceive potential plaintiffs as an enemy and held that as such they should not benefit from Israel in any way. They did not care that the State might incur costs. Rather, they cared that state funds might reach those they believed to be its foes, as Minister of Justice Meir Shitrit argued in one of the Committee's meetings regarding Amendment 4:

The Bill that was tabled is meant to prevent false claims against Israel. There is almost no country in the world that pays compensation during armed conflicts, or even opens the door to those people who might be injured in such a conflict to file a claim against it...the 260 million ILS that were paid were deducted from the Ministry of Defense' budget...The purpose is to prevent the state from paying those who tried to kill its combatants (Protocol 405).

In a later session, he was even more explicit:

There is no country in the world, only a foolish country, that provides its enemies with the option of suing it and getting compensation. We are the only foolish country that allows such a thing (Protocol 493).

MK Dov Hanin, who participated in the deliberations regarding the amendments, argued that discussions about the amendments should not be understood as about who should bear the financial costs of warfare from an objective economic perspective. Rather, according to Hanin, these discussions were about grounding a political standpoint that is rooted in the dynamics of the ongoing conflict between Israel and Palestine: 
The perception [of those who supported the amendment to the exception] is political. They don't want a situation in which Palestinians can vindicate their rights generally...The financial story there had no real meaning. It is not the type of financial deliberations that take place in the Knesset... You have to be from another planet to think that there were financial arguments here... This story didn't arise because someone wanted to cut a certain line in the budget. No one looked at the budget and said 'Hey, we have a problem here, let's save Israel some money'. What bothered them more was the possibility that an Israeli court would say the state acted wrongly. They didn't want that option (Interview with MK Dov Hanin).

MK Hanin's view is supported by the attitudes that combatants expressed towards nonIsraelis' tort claims during the Committee's deliberations. These combatants believed that Palestinian civilians were bringing tort claims against Israel for the losses they sustained as a tactic to weaken Israel. Put differently, tort claims were perceived as a continuation of warfare through civilian means, with plaintiffs as enemy combatants and tort claims as the weapon. For example, Lieutenant Colonel Mosheh Fisher maintained that:

Now we see their intentions. They say: let's use the civilian population to strike...This is a very generous Jewish offer in our view to turn the other cheek, let them strike us economically as well, that hundreds of millions of ILS will not go to our poor (Protocol 502).

Likewise, Colonel Yilon Farhi stated:

In recent years, we are encountering a growing phenomenon of Palestinian 
claims. When I asked myself why this is happening two possibilities come to mind. One, we might be getting more barbaric, and I have to say that...this does not add up...Today's Israeli society... is very moral... The other option is that somebody is using a legal loophole as a weapon against us...My personal estimation is that the Palestinians, encouraged by the lawyers who earn a living from them, take advantage of our morality as a weapon against us (Protocol 511).

This perception of Palestinians' tort claim as part of warfare is also shared by some government attorneys as is evident from similar views that were voiced in the deliberations of the Constitution, Law, and Justice Committee and by some of my interviewees. For instance, Government attorney GA3 said that "you don't want outside forces to dictate the national priorities and budget, and in this case it was hostile outside forces who don't have Israel's best interest at heart." Likewise, Advocate Kalhoora stated that:

We are not asking: the state is poor, it cannot deal with these cases, help, save us money, and so on...The result of the inability to deal with these claims in court is that the state of Israel will lose these cases, and will have to bear the costs of the other side to the conflict (Protocol 489).

In a study conducted by Gilat Bachar, government attorney described the expansion of the combatant activities exception as follows:

Our determination in the war against these cases paid off [...] The insight was that if we would be determined and fight with full force - without paying anything - at some point the other side will realize that it doesn't pay off to bring 
these cases $(2017,858)$.

Bachar also notes that in her interviews, government attorneys often used military-related phrases such as "joining forces", "platoon", and "war of attrition" in order to depict what they perceived to be their part in the "battle" against claims for losses inflicted by the IDF in what the government attorneys viewed as combatant activities $(2017,856)$. It seems that government attorneys view themselves as acting in a way that compliments, and perhaps is even a part of, the military's belligerent activities.

I will refer to this treatment of tort claims and their regulation as means of warfare as "tortfare", and it has two complimentary elements. First, it is the identification of or belief in tort litigation as a form of combat. Government attorneys are not merely reacting to something that happened on the battlefield, they see themselves in an active theater of operations. The courtrooms are the battlefield, plaintiffs and lawyers are the combatants, and the weapon being used is the law. Second, tort law and its regulation are re-designed and deployed to facilitate or support actual military goals. Such use could be found in Israel, when its courts imposed punitive damages on the Palestinian National Authority for losses incurred by Jewish Israeli nationals in terrorist activities (The Estate of Mantin v. The Palestinian Authority; The Estate of Ben Shalom v. The Palestinian Authority). The US has also enacted laws that enabled it to act in a similar ways against Syria, Iran, and Afghanistan, for example (28 U.S.C. § 1605A; Abraham 2019b).

The significance of identity as a factor in this context is also evident in the survey results. As is indicated in Figure 2 and Table 1, the identity of the bearer of liability has a statistically significant effect on the level of deterrence indicated by respondents, as does the nationality of the individuals towards whom compensation is owed. Respondents reported higher levels of deterrence in the hypothetical scenarios in which liability could be imposed on them as opposed 
to the State, as well as when liability was to be owed to enemy civilians rather than their fellow citizens.

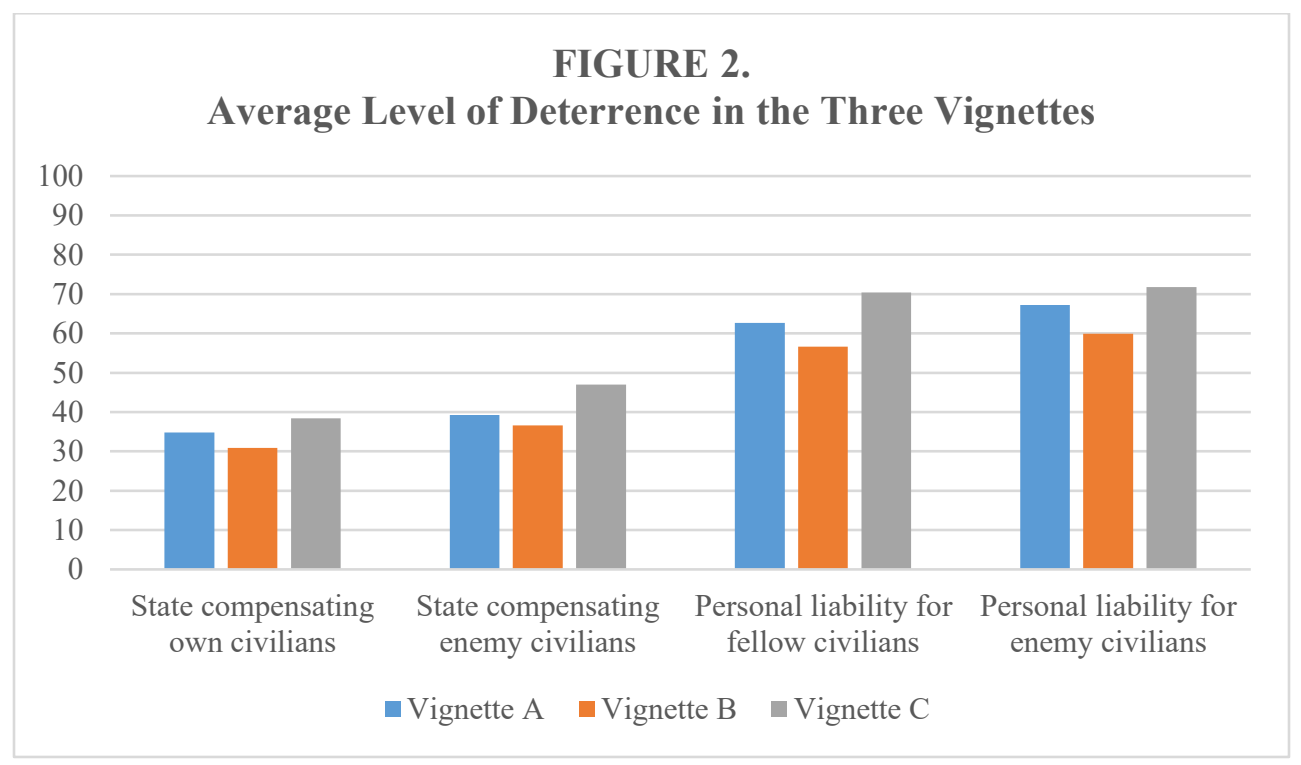

NotE: $\mathrm{N}_{\mathrm{A}}=287 ; \mathrm{N}_{\mathrm{B}}=233, \mathrm{~N}_{\mathrm{C}}=217$. Level of deterrence measured on a -100 scale.

\section{TABLE 1. Paired Sample T-Tests of Level of Deterrence}

\begin{tabular}{lcccccc}
\hline & \multicolumn{2}{c}{ Vignette A } & \multicolumn{2}{c}{ Vignette B } & \multicolumn{2}{c}{ Vignette C } \\
\cline { 2 - 6 } & Me/State & Foreign/Domestic & Me/State & Foreign/Domestic & Me/State & Foreign/Domestic \\
& $27.932^{* * * *}$ & $4.548^{* * *}$ & $24.536^{* * *}$ & $4.476^{* *}$ & $28.410^{* * *}$ & $4.940^{* * *}$ \\
& 1.973 & 1.459 & 2.153 & 1.627 & 2.196 & 1.641 \\
\hline SE & 287 & 287 & 233 & 233 & 217 & 217 \\
\hline
\end{tabular}

NOTE: Level of deterrence measured on a scale of $0-100$.

$* p<.05 ; * * p<.01 ; * * * p<.001^{26}$

Additionally, there are also indications in the survey that the amount of compensation owed to the injured party is statistically significant, as is illustrated by Figure $4 .{ }^{27}$ Respondents' level of 
deterrence was higher when the hypothetical scenario presented to them suggested that liability will be for the amount of five million ILS, and lower when it was for 500 ILS (equivalent to roughly 1.5 million USD and 150 USD correspondingly). This result seems intuitive. The higher the risk, the greater effect it should have.

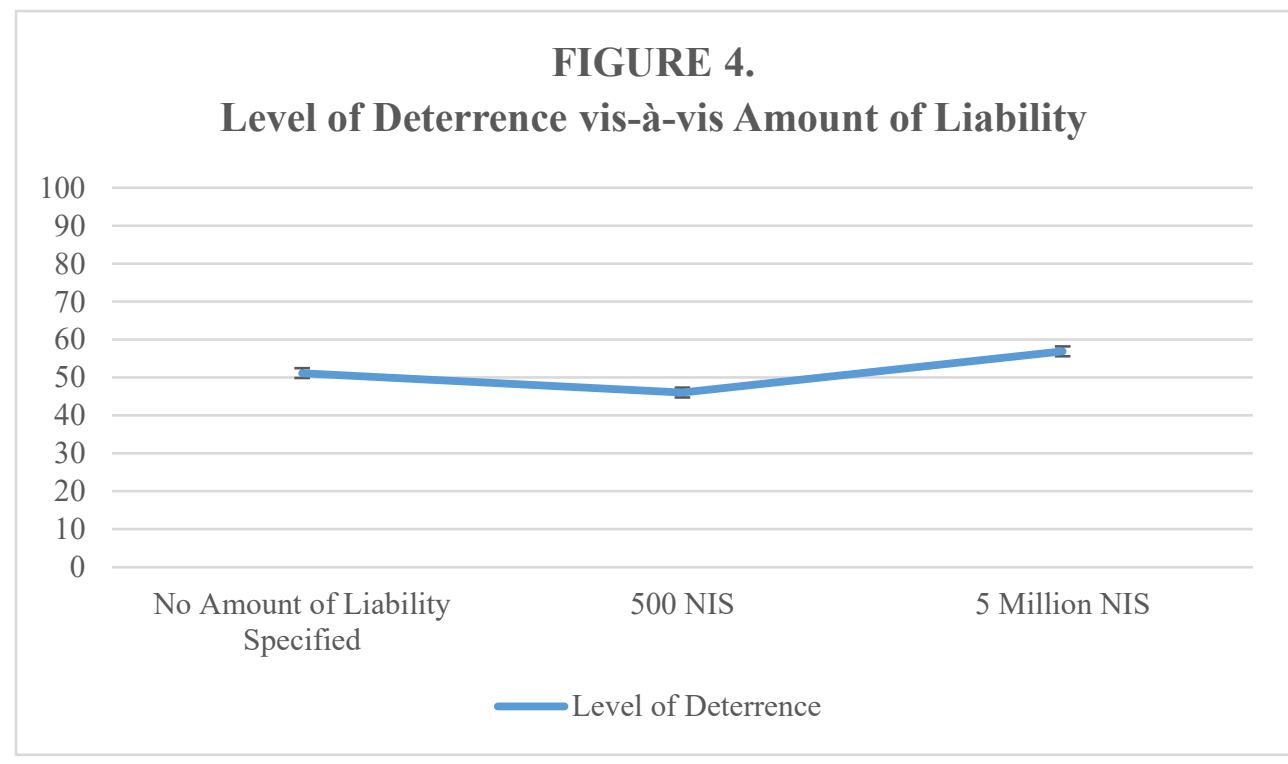

NoTE: Level of Deterrence measured on a scale of 0-100.

Still, the significance of the actual pecuniary costs of an imposition of tort liability is not in the effect pecuniary costs have on the state's ability to engage in combatant activities. In fact, state actors seem to be somewhat indifferent to pecuniary costs in this sense. As government attorney GA2 argued: "the MoD is a body with a budget of billions [of ILS]. These cases [tort cases that arise from combat activities] are peanuts." Furthermore, all three groups of actors have indicated that tort liability is not accounted for when deciding if and how to engage in warfare.

Rather, what seems to matter is what an imposition of tort liability symbolizes. A positive ruling of a court for a plaintiff in any tort claim means that the defendant has committed a wrong against the plaintiff. In the context of tort liability for losses that were inflicted during warfare, 
such a finding would mean that Israel, through the operation of its security forces, wronged an individual - most commonly a Palestinian individual.

Some state actors might take these ruling personally, despite the fact that they were not defendants, nor do they personally should the costs of liability. Government attorney GA1 expressed that "in cases against the state, especially on sensitive subjects like the Intifada, you feel the State's loss...It is not just a sense of personal success that drives you, it is a sense of justice towards the State...It is a sense of the State is me, like Louis XIV."

Other state actors might view such instances of impositions of liability as a sign that something in the law should be amended to better reflect what they believe to be the right result in similar future cases. As government attorney GA3 stated: "You know that there is a problem when you deal with a topic too much, or you pay too much, or that the courts criticize you, or that you spot something illogical and problematic, either in a single major case or over a series of many similar cases." Put differently, a single high-profile case or a series of similar low-profile cases could motivate actors to amend the law, but this result depends on whether an issue caught an actor's attention. As the data above indicate, the attention of multiple state actors was caught when multiple tort claims were filed and won by Palestinian plaintiffs in relation to the operations of the State's security forces.

\section{LESS LIABILITY DOES NOT MEAN ACTING WITH GREATER CARE}

The above data suggest that tort liability for belligerent activities is under-deterring. Politicians, combatants, and government attorneys indicated that when it comes to warfare, an imposition of tort liability and the pecuniary costs of liability are irrelevant factors in the decision-making process. Even though they did seem to care about what the principle that an imposition of liability 
for wrongs that were inflicted during battle represented to them, it did not affect their consideration as to whether to engage in belligerent activities and how to conduct them. Put differently, the study demonstrates that tort liability did not prompt the relevant state actors to act more carefully when engaging in combat.

Rather, state actors cared about other considerations, such as promoting security interests by achieving military goals, or abolishing the possibility that a court would find that the state or its combatants have committed a wrong against the enemy's civilian population. In this respect, tort liability under-deterred the various actors, and hence the State, from deciding to engage in combat, how to conduct belligerent activities, or refrain from battle altogether.

Moreover, the three preconditions for deterrence - choice, information, and internalization of costs - are lacking to various degrees during warfare. While politicians believe that they have complete freedom to choose whether to engage in combat, they do not necessarily have the knowledge to determine how to do so. Instead, they defer to high-ranking combatants, who decide how and when to act, and lower-ranking combatants sometime maintain some degree of choice as well. Still, once a legitimate order has been given, either by politicians to high-ranking combatants or by high-ranking combatants to lower-ranking combatants, then there is no choice regarding whether to engage in a combatant activity. Furthermore, while government attorneys advise both politicians and combatants on the legality of their activities, they do not decide about whether certain activities will be engaged in or refrained from, and their advice generally supports rather than hinders combat.

As for the information precondition, government attorneys seem to be the best informed of all three groups of state actors in relation to the risks of tort liability. They are an information hub, but their ability to spot patterns, analyze cases, and offer feedback to politicians and combatants is 
limited due to structural and budgetary deficits. Information is mostly gathered by individual attorneys and passed on an ad hoc basis, which makes retention, examination, and transfer of knowledge difficult. Even when such knowledge exists, all three groups of actors do not conceive of potential tort liability as a relevant consideration in relation to whether and how to conduct belligerent activities, and so it is not passed on.

However, it is the third precondition for deterrence - the internalization of the costs of wrongdoing - that is not met most evidently. No individual of any group of state actors bears the costs of wrongdoing, mainly as it is the state that is sued, not individual public officials, and due to the general immunities public officials enjoy. Even in instances in which an individual official is sued, and she is not immune, the state will subrogate or indemnify her. In addition, the costs of liability do not impact the operation of any group of actors. Instead, they are either budgeted for in advance or that funds are procured from the Ministry of Finance, neither instance has a negative effect on the budget of a group of actors or their ability to operate. In this sense, it seems that the state's deep pockets make the pecuniary costs financially unremarkable, even though their aggregated amount is in the hundreds of millions of USD.

Nevertheless, the imposition of tort liability had a noteworthy side-effect in the particular context of warfare. As the study reveals, tort litigation and liability prompted politicians and government attorneys to pursue three initiatives. First, they have considerably expanded the scope of the combatant activities exception to a degree that its constitutionality is questionable. The exception applies to losses that are not necessarily of a combatant character, but also to those of a policing character. Furthermore, immunity is granted against claims of civilians who are nationals or residents of an enemy's state regardless of the circumstances in which a loss was inflicted on them. ${ }^{28}$ Second, government attorneys pushed for the introduction of procedural requirements that 
make the filing of claims against the state very difficult, and hence restrict the number of tort cases that reach the courts. ${ }^{29}$ Third, Israel made it very challenging for Palestinian plaintiffs and their witnesses to obtain entry permits to testify, and so their ability to support their claims is partially, and at times entirely, frustrated..$^{30}$

Tort litigation and liability acted as a catalyst to the legislative and regulatory actions taken by Israeli politicians and government attorneys, aimed at ensuring that the losses that are inflicted during war will not be shouldered by the State. These measures were not aimed at ensuring that the State will take greater care to avoid inflicting losses on civilians. Nor was the expansion of the immunity aimed at eliminating the possibility that liability will deter combatants from engaging in warfare, or even that the costs of litigation will be too high for the State to be able to withstand. Rather, these legislative and regulative measures were aimed at limiting courts' ability to hold that the State acted wrongly. By preventing Palestinians from filing claims against Israel in an increasing range of circumstances, there are fewer instances in which courts can reach the conclusion that the State committed a tortious wrong. Additionally, as the procedural and substantive hurdles to litigation increased, the number of claims being brought and pursued until a ruling has been given decreased, further limiting the possibility that Israel acted wrongly.

While this regulatory side-effect cannot be conceptualized in the ordinary terms that tort scholars use to describe deterrence, as it does not directly influence actors' decision to engage in a potentially wrongful activity, it nevertheless has a secondary indirect influence on actors' incentives. Once the liability regime has been amended, the incentive structure changes correspondingly. The current revised liability regime results in even less incentives to avoid wrongdoing, as the State and its agents enjoy a near blanket immunity from liability.

As the findings of this study show, tort liability and litigation can prompt state actors to act 
in ways that are not predicted or prescribed by the theoretical hypotheses scholars thus far have offered. State actors did not respond solely to impositions of liability, but also to the number of cases being litigated. They developed reasons to expand the scope of the state immunity from liability, even though they did not bear liability themselves. The number of cases in which a court found the State to have inflicted a wrongful loss dropped, but not because state actors learned from each imposition of liability how they should act more carefully. There is no evidence that the rules of engagement or policing activities protocols have changed in response to an imposition of tort liability. Rather, the reason for fewer positive findings of wrongdoing seems to be the expansion of the combatant activities exception. It is, therefore, highly important to be cognisant of the regulatory side-effect that tort litigation and liability has on state actors.

\section{CONCLUSIONS}

In this paper, I tested the hypothesis that an imposition of tort liability for losses that are inflicted during battle would not result in the over-deterrence of the state or its agents from engaging in belligerent activities. For this purpose, I conducted an exploratory study, using a mixed-methods approach and Israel as a test-case. The results of this study suggest that the imposition of tort liability under-deter state actors from engaging in belligerent activities. My data indicate that the three necessary preconditions for deterrence to occur (choice, information, and internalization of costs) are not met to various degrees by politicians, combatants, and government attorneys. State actors are not fully free to choose their course of action, they lack accurate information about the costs that are associated with various possibilities of action and inaction, and they do not internalize the costs of inflicting wrongful losses. Moreover, state actors have expressed that neither the possibility of an imposition of tort liability nor actual instances in which it was imposed influence 
their decision about whether to engage in belligerent activities or how to conduct them. Therefore, I argue that there are indications that tort liability under-deterrers state actors from engaging in wrongful belligerent activities.

This study yields three important insights. First, it demonstrates that for public actors, tort law is not just about financial considerations and implications. Instead, actors might also, or even primarily, be mindful of other issues that they associate with an imposition of liability that are not strictly about costs. These considerations could be, for instance, about the political implications of tort liability, the internal coherence of tort law when applied to the battlefield, efficient administration of justice, or even just about feeling over-burdened with work.

Second, this study highlights how tort law affects public officials and public bodies in a way that is not limited to their considerations of whether and how to engage in an activity. Rather, tort liability could also have a regulatory side-effect that influence actors' deterrence from tort law in a secondary and indirect fashion. While discourse on the effects of tort liability tend to focus on how it can directly alter actors' decision whether to engage in activities and how to conduct themselves, this study reveals another effect that is unique to public actors and bodies. These actors can control the risk of liability they are exposed to not only by choosing whether and how to act, but also by regulating what is a wrongful action, who can access courts, and under which conditions. This ability can be abused by granting a vast immunity from liability that prevents private individuals from being able to stand on their rights and hold state actors liable for inflicting wrongful losses on them.

Third, my findings suggest that there might be a possibility of prompting states actors into acting with an adequate degree of care in the context of warfare through impositions of tort liability, without causing over-deterrence. The key seems to lie in the fact that state actors care 
about impositions of liability on the state even though they do not bear the costs of liability themselves, and despite the fact that security considerations take precedence. As the findings of this study suggest, the motivation to minimize potential exposure to tort liability seems to have been driven primarily by factors other than a fear of over-deterring combatants or that tort litigation might be too costly. Rather, state actors view the possibility of courts finding the State's conduct as tortiously wrongful as worrying, and thus far have avoided this negative result by granting the State an immunity from liability rather than by amending their conduct.

Still, there is reason to believe that if courts were able to declare that the State's conduct was wrongful, then the relevant public actors could be incentivized to refrain from acting wrongfully in the future. Such effect was achieved, for example, through the Supreme Court of Israel's rulings in relation to the IDF's practice of using Palestinians as human shields, by having them knocking on their neighbors' doors and informing them of their immanent arrest. The Supreme Court held that this practice was contrary to the Laws of Armed Conflict that the State cannot exempt itself from, and is therefore prohibited (Adallah v. Central Command's Major General, 81). Consequently, the IDF reported that it ceased its practice (Bochbut 2005). ${ }^{31}$ Similarly, even if state actors will be indifferent to the pecuniary costs of a finding of liability, the symbolic and reputational meaning of an imposition of liability might cause them to act with greater care.

However, incentivizing state actors through court rulings could be achieved only if the combatant activities exception is abolished or constrained, and provided that government attorneys are sufficiently independent from other state actors. A major factor that seemed to have contributed to the expansion of Israel's immunity from tort liability was that government attorneys saw themselves as participating in the war efforts, and litigation as a mode of combat that I described 
above as "tortfare". Government attorneys aspired to find ways to facilitate Israel's use of armed force, without properly considering the implications of the expansion of the State's immunity. As such, they advanced reforms and regulations that severely limited potential plaintiffs' ability to seek and obtain tort law remedies for their injuries, resulting in near blanket immunity from liability. The current regime yields much weaker incentives than that of the original 1952 combatant activities exception, which merely stated that Israel is not "liable in tort for a combatant activity committed by the Israel Defense Forces." For government attorneys to be able to offer comprehensive and unbiased advice, they must be sufficiently structurally and conceptually independent from the other state actors whom they advise. From an objective position, the law could be examined and structured in a way that provides actors with better incentives to comply with the law and avoid wrongdoing; not merely with ways to evade a finding of wrongdoing without taking greater care.

Ultimately, striking the right balance between deterrence and liability depends on one's approach to tort law. ${ }^{32}$ Yet, the ability to hold the State liable in tort and the availability of independent legal advice are clearly necessary elements in this process. Only with these elements in place the right balance between deterring state actors and protecting individuals' rights and social standing could be achieved.

\section{REFERENCES}

Abraham, Haim. 2019a. 'Tort Liability for Belligerent Wrongs'. Oxford Journal of Legal Studies 39 (4): 808-33. https://doi.org/10.1093/ojls/gqz025. 
_.2019b. 'Awarding Punitive Damages Against Foreign States Is Dangerous and Counterproductive'. Lawfare. 1 March 2019. https://www.lawfareblog.com/awardingpunitive-damages-against-foreign-states-dangerous-and-counterproductive.

Bachar, Gilat. 2017. 'Access Denied-Using Procedure to Restrict Tort Litigation: The IsraeliPalestinian Experience'. Chicago-Kent Law Review 92 (3): 841-70.

Benbenisty, Yizhaq, Uzi Ben-Shalom, and Ziv Ronel. 2010. 'The Guys Aren't Everything: The Motivation to Fight in Operation "Cast Lead". Systems: The Israel Defense Forces' Journal, 2010, 430 edition.

Ben-Naftali, Orna, Michael Sfard, and Hedi Viterbo. 2018. The ABC of the OPT: A Legal Lexicon of the Israeli Control Over the Occupied Palestinian Territory. Cambridge University Press.

Blau, Uri, and Yotam Feldman. 2009. 'How IDF Legal Experts Legitimized Strikes Involving Gaza Civilians'. Haaretz, 22 January 2009. www.haaretz.com/how-idf-legal-expertslegitimizedstrikes-involving-gaza-civilians-1.268598.

Blum, Gabriella, and Natalie J. Lockwood. 2013. 'Earthquakes and Wars'. In Jus Post Bellum and Transitional Justice, edited by Larry May and Elizabeth Edenberg, 178-216. Cambridge: Cambridge University Press. https://doi.org/10.1017/CBO9781139628594.007.

Bochbut, Amir. 2005. 'The IDF Is Aborting the "Neighbor Protocol"'. Maariv, 7 October 2005. https://www.makorrishon.co.il/nrg/online/1/ART/993/808.html.

Bradley, Anthony, and John Bell. 1991. 'Governmental Liability: A Preliminary Assessment'. In Governmental Liability: A Comparative Study, edited by Harry Street, 1-16. Archon Books. 
Calabresi, Guido. 1970. The Costs of Accidents: A Legal and Economic Analysis. New Haven: Yale University Press.

Calabresi, Guido, and Jon T. Hirschoff. 1972. 'Towards a Test for Strict Liability in Torts'. Yale Law Journal 81: 1055-85.

'Canada, Parliament, House of Commons Debates, 21st Parliament, 7th Session, Vol. 4, 3326 (March 26, 1953)'. http://parl.canadiana.ca/view/oop.debates_HOC2107_04/36?r=0\&s=3.

Chapman, Bruce. 1996. 'Corporate Tort Liability and the Problem of Overcompliance'. Southern California Law Review 69 (5): 1679-1704.

Clausewitz, Carl von. 2008. On War (1832). Edited by Michael Eliot Howard and Peter Paret. Princeton: Princeton University Press.

Cooter, Robert, and Thomas Ulen. 2008. Law \& Economics. 5th ed. Pearson/Addison Wesley. Craig, Alan. 2013. International Legitimacy and the Politics of Security: The Strategic Deployment of Lawyers in the Israeli Military. Lanham: Lexington Books.

Crootof, Rebecca. 2016. 'War Torts: Accountability for Autonomous Weapons'. University of Pennsylvania Law Review 164 (6): 1347-1402.

Englard, Izhak. 1993. The Philosophy of Tort Law. Aldershot; Brookfield USA: Dartmouth. Ewick, Patricia, and Silbey, Susan S. 1998. The Common Place of Law: Stories from Everyday Life. University of Chicago Press: Chicago.

Fairgrieve, Duncan. 2002. 'Pushing Back the Boundaries of Public Authority Liability'. In Tort Liability of Public Authorities in Comparative Perspective, edited by Duncan Fairgrieve, Andenas Mads, and John Bell, 475-98. The British Institute of International and Comparative Law. 
Feldthusen, Bruce. 1993. 'If This Is Torts, Negligence Must Be Dead'. In Tort Theory, edited by Ken Cooper-Stephenson and Elaine Gibson, 394. Captus Press.

Fleming, John G. 1984. 'Is There a Future for Tort?' Louisiana Law Review 44: 1193-1212.

Gardner, John. 2011. 'What Is Tort Law For? Part 1. The Place of Corrective Justice'. Law and Philosophy 30 (1): 1-50. https://doi.org/10.1007/s10982-010-9086-6.

Geva, Maayan. 2019. 'Military Lawyers Making Law: Israel's Governance of the West Bank and Gaza’. Law \& Social Inquiry 44 (03): 704-25. https://doi.org/10.1017/1si.2018.31.

Goldberg, Helene M. 2002. 'Tort Liability for Federal Government Actions in the United States: An Overview'. In Tort Liability of Public Authorities in Comparative Perspective, edited by Duncan Fairgrieve, Mads Andenas, and John Bell, 521-39. London: The British Institute of International and Comparative Law.

Goldberg, John C. P. 2003. 'Twentieth-Century Tort Theory'. Georgetown Law Journal 9: 51383.

Harlow, Carol. 2004. State Liability: Tort Law and Beyond. Clarendon Law Lectures. Oxford; New York: Oxford University Press.

Henriksen, Rune. 2007. 'Warriors in Combat - What Makes People Actively Fight in Combat?' Journal of Strategic Studies 30 (2): 187-223. https://doi.org/10.1080/01402390701248707.

Interview with Advocate Ahaz Ben Ari (February, 2019).

Interview with Brigadier General Sasson Hadad (February, 2019).

Interview with Colonel Gabi Siboni (February, 2019).

Interview with Colonel IDF1 (January, 2019) (IDF).

Interview with GA1 (February, 2019) (Government Attorney). 
Interview with GA2 (February, 2019) (Government Attorney).

Interview with GA3 (February, 2019) (Government Attorney).

Interview with Major General IDF3 (January, 2019) (IDF).

Interview, MK Major General IDF2 (January, 2019) (IDF).

Interview with MK Deputy Commissioner David Tsur (February, 2019).

Interview with MK Dov Hanin (February, 2019).

Jacob, Assaf. 2003. 'Immunity Under Fire: State Immunity from Harm Caused Due to "Combatant Activity"'. The Hebrew University Law Review 23: 107.

Jacob, Joseph M. 1992. 'The Debates Behind an Act: Crown Proceedings Reform, 1920-1947'. Public Law 92: 452-84.

Jones, Michael D. 2010. 'Consistency and Equality: A Framework for Analyzing the "Combat Activities Exclusion” of the Foreign Claims Act'. Military Law Review 204: 144-80.

Kellett, Anthony. 1982. Combat Motivation: The Behavior of Soldiers in Battle. International Series in Management Science/Operations Research. Boston : Hingham, Mass: KluwerNijhoff Pub. ; Distributors for North America, Kluwer Boston.

Kerr, Margaret Helen, Laurence M. Olivo, and JoAnn Kurtz. 2014. Canadian Tort Law in a Nutshell. Carswell.

Lev, Shay. 2015. 'Request of Information in Accordance with The Freedom of Information Act 1998', 3 August 2015.

Pfander, James E., Alex Reinert, and Joanna C. Schwartz. 2019. 'The Myth of Personal Liability: Who Pays When Bivens Claims Succeed'. Stanford Law Review, Forthcoming. https://papers.ssrn.com/sol3/papers.cfm?abstract_id=3343800.

Posner, Richard. 1972. 'A Theory of Negligence'. Journal of Legal Studies 1: 29. 
'Protocol 49, Constitution, Law, and Justice Committee, August 13, 1952'.

'Protocol 66, Constitution, Law, and Justice Committee, September 14, 2009, 09:00'.

'Protocol 81, Constitution, Law, and Justice Committee, October 19, 2009, 10:00'.

'Protocol 405, Constitution, Law, and Justice Committee, December 25, 2001, 12:00'.

'Protocol 489, Constitution, Law, and Justice Committee, May 31, 2005, 10:20'.

'Protocol 493, Constitution, Law, and Justice Committee, June 24, 2002, 11:30'.

'Protocol 497, Constitution, Law, and Justice Committee, June 26, 2002, 10:30'.

'Protocol 502, Constitution, Law, and Justice Committee, June 15, 2005, 09:00'.

'Protocol 511, Constitution, Law, and Justice Committee, June 23, 2005, 10:00'.

'Protocol of the 185 Session of the Second Knesset'. 1952.

Randall, Susan. 1993. 'Corrective Justice and the Torts Process'. Indiana Law Reviw 27 (1): 150.

Reuters staff. 2017. 'Turkey Says Israel Paid Compensation to Families of 2010 Flotilla Raid Victims'. Reuters, 23 June 2017. https://www.reuters.com/article/us-turkey-israelcompensation/turkey-says-israel-paid-compensation-to-families-of-2010-flotilla-raidvictims-media-idUSKBN19E166.

Ripstein, Arthur. 2005. 'In Extremis'. Ohio State Journal of Criminal Law 2 (2): 415-34.

Schuck, Peter H. 1983. Suing Government: Citizen Remedies for Official Wrongs. New Haven: Yale University Press.

Schwartz, Gary T. 1997. 'Mixed Theories of Tort Law: Affirming Both Deterrence and Corrective Justice'. Texas Law Review 75: 1801-34.

—. 2002. 'Empiricism and Tort Law'. University of Illinois Law Review 2002: 1067-82. 
Shavell, Steven. 2004. Foundations of Economic Analysis of Law. Belknap Press of Harvard University Press.

Shaw Savill \& Albion Co. v. Commonwealth. (1940) 66 C.L.R. 344.

'State Attorney Directive 16.5 - The Vicarious Liability of the State and the Immunity of Public Officials in Tort'. 2003. http://www.justice.gov.il/Units/StateAttorney/Guidelines/016.5.pdf.

Statman, Daniel, Raanan Sulitzeanu-Kenan, Micha Mandel, Michael Skerker, and Steven De Wijze. 2020. 'Unreliable Protection: An Experimental Study of Experts' In Bello Proportionality Decisions'. European Journal of International Law 31 (2): 429-53.

Sugerman, Stephen D. 1989. Doing Away with Personal Injury Law. Quorum Books.

Surma, Ralph-Andreas. 2002. 'A Comparative Study of the English and German Judicial Approach to the Liability of Public Bodies in Negligence'. In Tort Liability of Public Authorities in Comparative Perspective, edited by Duncan Fairgrieve and Mads Andenas, 355-99. The British Institute of International and Comparative Law.

The Economist. 2012. 'Rockets Galore’, 29 September 2012. https://www.economist.com/science-and-technology/2012/09/29/rockets-galore.

Tugendhat, Thomas, and Laura Croft. 2013. 'The Fog of Law: An Introduction to the Legal Erosion of British Fighting Power'. Policy Exchange. https://policyexchange.org.uk/wpcontent/uploads/2016/09/the-fog-of-law.pdf.

Voyiakis, Emmanuel. 2018. 'Causation and Opportunity in Tort'. Oxford Journal of Legal Studies 38 (1): 26-47. https://doi.org/10.1093/ojls/gqx018.

Weinrib, Ernest J. 2002. 'Deterrence and Corrective Justice'. University of California, Los Angeles Law Review 50: 621-40. 
White, Patrick. 2019. 'Lawyers Sound Alarm Over New Law That Could Limit Lawsuits Against Ontario Government'. The Globe and Mail, 16 April 2019. https://www.theglobeandmail.com/canada/article-lawyers-sound-alarm-over-new-lawthat-could-limit-lawsuits-against/.

Wong, Leonard, Thomas A. Kolditz, Raymond A. Millen, and Terrence M. Potter. 2003. 'Why They Fight: Combat Motivation in the Iraq War'. Carlisle Barracks: Strategic Studies Institute. https://permanent.access.gpo.gov/lps35591/whyfight.pdf.

\section{LEGISLATIONS CITED}

28 U.S.C. $\$ 1605(a)(5) .1976$.

28 U.S.C. $\S 1605 A$.

28 U.S.C. $\$ 1346.1948$.

Civil Wrongs (State Liability) Act. 1952.

Crown Liability and Proceedings Act (R.S.C., 1985, c. C-50). 1985.

Draft Bill 108 Civil Wrongs (State Liability), 5712-1952.

Draft Bill 387 Civil Wrongs (State Liability) (Amendment 8). 2008.

Draft Bill 2645 for the Treatment of Claims Against the Security Forces' Operations in Judea and Sameria and the Gaza Strip, 5757-1997, 497.

Draft Bill 2645 Handling Lawsuits Against the Operations of the Security Forces in Judea and Samaria and Gaza (Amendment 4). 1997.

Draft Bill 3173 Civil Wrongs (State Liability) (Amendment 7). 2005.

Foreign States Immunities Act. 1985.

Foreign States Immunity Act. 2008. 
Security Service Act. 1986

State Immunity Act. 1978.

State Immunity Act, R.S.C., 1985, c. S-18. 1985.

Tort Ordinance. 1968.

War Damage Act. 1965.

\section{CASES CITED}

Anns and others v London Borough of Merton. [1977] 2 All ER 492.

CA 311/59 Mifal Takhanot Hatraktorim Ltd. v. Hayat. 1960 PD 141609.

CA 542/75 Atallah v. Israel. PD 31(2) 552 (1997).

CA 623/83 Levi v. Israel. 1986 PD 4(1) 447.

CA 1459/11 The Estate of Hardan v. Israel. (Nevo, June 16, 2003).

CA 2144/13 The Estate of Mantin v. The Palestinian Authority. (Nevo, December 6, 2017).

CA 5964/92 Jamal Kasam Bani Uda v. Israel. 57(4) PD 1 (2002).

CA 6982/12 The Estate of Corrie v. Israel (Nevo, February 12, 2015).

CC (Beer Sheva) 636/87 Abu Shamisa v Judea and Sameriya Military Commander. (Nevo, 1994).

CC (Beer Sheva) 45043-05-16 A v. Israel. (Nevo, November 4, 2018).

CC (Jerusalem) 317/93 Abu Jabar v. Israel, TK-District 94(3) 6. 1994.

CC (Jerusalem) 3361/09 The Estate of Ben Shalom v. The Palestinian Authortiy. (Nevo,

November 17, 2017).

HCJ 3799/02 Adallah v. Central Command's Major General. 2005 PD 60(3).

HCJ 4146/11 Hass and others v. The Chief of Staff. (Nveo, July 09, 2013). 
HCJ 7042/12 Abu Dakah v. Minister of Interior. (Nevo, December 16, 2014).

HCJ 8276/05 Adallah v. Minister of Defense. PD 62(1) 1 (2006).

HCJ 10265/05 Doctors for Human Rights v. The Minister of Defense. (Nevo, October 7, 2008).

Ibrahim v. Titan Corp. 391 F Supp 2d 10 (DDC 2005).

Johnson v. United States. 170 F.2d 767 (9th Cir. 1948).

Kamloops (City) v Nielsen. [1984] 2 SCR 2.

Koohi v. United States. 976 F.2d 1328 (1992).

Mulcahy v. Minister of Defence. [1996] QB 732.

Saleh v. Titan Corp. 580 F.3d 1 (CADC, 2009).

\section{FOOTNOTES}

* Lecturer, Faculty of Laws, University College London haim.abraham@ucl.ac.uk. Drafts of this paper were presented at the McGill University Global Seminar on Private Law Theory, Oxford Institute for Ethics, Law and Armed Conflict, Work-in-Progress Seminar; Stanford Law and Society Conference; University of Florida, Collage of Law, National Security Workshop; The Israeli Private Law Association Annual Conference; and The Hebrew University, Empirical Studies of Public Law and Human Rights Conference. I thank the participants of these events for their helpful feedback. I am deeply indebted to Doron Dorfman, Noga Keidar, Amit Lazarus, and Vanina Leschziner for their valuable input and guidance in developing this study and analyzing its results. I would also like to thank Omri Ben-Zvi, Kathleen Claussen, David Dyzenhaus, John Enman-Beech, Rory Gillis, Talia Gillis, Amalia Kessler, Dimitrios Kyritsis, Naama Ofrath, Arthur 
Ripstein, Eden Sarid, Maurice Sunkin, Emmanuel Voyiakis, Ernest Weinrib, Ingrid Wuerth and the anonymous reviewers for their insightful comments.

${ }^{1}$ There are other justifications for the combatant activities exception that are based on different approaches to tort law, such as the incompatibility of an imposition of liability in the context of warfare with victim compensation and punishment of wrongdoers (Koohi v. United States, 1331). Delving into which approach to tort liability is relevant in this context, as well as to the implications they might have, goes beyond the scope of this paper, and there is no need to venture into these realms to examine whether tort liability might deter actors from engaging in combat.

${ }^{2}$ See, for example: 28 U.S.C. $§ 1346$, (1948); Section 8 of the CROwn LiabiLITY AND PROCEEDINGS ACt (R.S.C., 1985, C. C-50); Section 5 of the Civil Wrongs (State Liability) ACt (1952); Section 1 of the War Damage Act 1965; Shaw Savill \& Albion Co. v. Commonwealth, 361-63; Mulcahy v. Minister of Defence, 748-49.

${ }^{3}$ I will not engage in an examination of the effects of international, criminal, and administrative laws on state actors, or attempt to identify a taxonomy of all factors that influence the relevant state actors in deciding whether to engage in belligerent activities (Wong et al. 2003; Henriksen 2007; Kellett 1982; Benbenisty, Ben-Shalom, and Ronel 2010). Nor will I assess what could amount to a wrong during warfare (Abraham 2019a). Rather, the scope of my research is limited to the examination of the effects of an imposition of tort liability for losses caused through engagement in belligerent activities.

${ }^{4}$ My analysis relied on cases that are available in Israel's leading databases (Nevo and Takdin), as well as on access to court records in cases that are not publicly available online. At the first stage I conducted several Boolean searches, focusing on cases citing the combatant activities exception, as well as keywords such as "combat", "liability", and "tort" that were in mentioned in the same 
paragraph. I compared the results of my searches to those cited by the court rulings decisions I analyzed and collected additional cases that were not publicly available online. Between 1951 and 2021, a total of 292 cases in which the combatant activities exception is discussed were found and analyzed. My content analysis focused on the result in each case (whether the exception was applied) as well as on the reasoning of the courts and the context in which each case arose. At the time in which this draft was sent for publication, there are no other cases known to me that discuss the combatant activities excetion.

${ }^{5}$ For an opposing view, see: Blum and Lockwood 2013, 212.

${ }^{6}$ This approach was adopted by the Supreme Court of Israel (Bani Uda v. Israel, 7; The Estate of Corrie v. Israel, 10; Adallah v. Minister of Defense, 33). Scholars have offered similar arguments. Assaf Jacob reasoned that tortious liability will incentivize combatants to refrain from engaging in battle as they "are exposed to harm but are not gaining the full benefit of their actions personally" (2003, 129-30). Tom Tugendhat and Laura Croft raise similar concerns, and argue not only that combatants are going to be over-deterred, but that belligerent activities are going to be forestalled by the legal processes that stem from an existence of a tortious duty of care $(2013,54)$. See also: Jones 2010, 158.

${ }^{7}$ I refer to commanding officers as 'higher-ranking combatants' and to their subordinates as 'lower-ranking combatants', although at times I use the term 'combatants' to capture the entire range of ranks. Additionally, while I treat politicians, government attorneys, and combatants as distinct groups of actors, I am not suggesting that there cannot be instances in which an individual who is a member of one group is never a member of another group. In Israel, higher-ranking combatants often become politicians. Nor am I arguing that each group is internally homogenous. Indeed, individuals who belong to a particular group can have different views that might have 
implications on their incentive scheme. Still, for the purposes of this study, it is useful to think about the incentive structure that is unique to members of each group.

${ }^{8}$ In Israel, government attorneys were the ones who initiated the legislative amendments aimed at expanding the combatant activities exception in response to the courts' rulings on the liability of the state for activities it perceived as combatant (Protocol 405). Furthermore, military legal advisors have been "incorporated into the decision-making process before and during each warfare activity, even if the lawyers are not formally the decision-makers" (Ben-Naftali, Sfard, and Viterbo 2018, 249-50).

${ }^{9}$ Deterrence is often conceptualized in instrumental terms that are based on an economic analysis of the law. If the marginal costs of avoiding an injury outweigh the marginal costs of the magnitude of loss times its probability of materializing, then actors are over-deterred (see, for example: Cooter and Ulen 2008, 349-53; Posner 1972, 32; Shavell 2004, 182-89). An optimal level of deterrence would be achieved when the liability regime results in the least amount of total costs (Calabresi 1970, 26-31; Calabresi and Hirschoff 1972, 1060; Posner 1972, 33).

Yet, deterrence can also be understood from a corrective justice perspective, which examines the incentives positive law provides to individuals to refrain from acting in ways that wrongfully infringe the rights of others (Weinrib 2002, 638-39; Ripstein 2005, 416-17; Chapman 1996, 1685). It is individuals' ability to anticipate liability due to tort law that produces deterrence (Gardner 2011, 24-25; Schwartz 1997, 1816-17). "Over-deterrence" occurs when the law can incentivize individuals to refrain from pursuing their ends, even when doing so will not be wrongfully infringing the rights of others. In contrast, "under-deterrence" occurs when positive law insufficiently guides individuals' behavior and fails to provide adequate incentives to refrain from wrongfully infringing the rights of others. 
${ }^{10}$ However, a common criticism is that information is rarely fully and accurately available to individuals prior to their actions, nor is it always fully available after the actions were completed and harm was done (Fleming 1984, 2000; Goldberg 2003, 559).

${ }^{11}$ A single Tomahawk cruise missile costs about \$1.5m USD alone: (The Economist 2012).

12 Arguably, deterrence has little to no impact when we act with inadvertent carelessness (Feldthusen 1993, 409; Randall 1993, 14). Moreover, the imposition of tort liability might not be justified when combatants do not have the opportunity to choose their course of action, and that they have no reason to value the possibility of having a choice under these circumstances (Voyiakis 2018, 31). That said, commanders who are not present in the theater of operations but are located in a shielded command post could potentially consider a cost-benefit analysis.

${ }^{13}$ For instance, discretionary policy and political decisions generally cannot be the subject of tort claims, unlike actions of an operational character (Koohi v. United States, 1331; Anns v London Borough of Merton; Kamloops v Nielsen; Goldberg 2002, 524), and public officials might enjoy other special immunities from personal liability. Therefore, individual politicians and government attorneys are unlikely to be the subject of a successful tort claim.

${ }^{14}$ In the United States, over $97 \%$ of Bivens actions against Federal Bureau of Prisons employees, defendants did not paid out-of-pocket (Pfander, Reinert, and Schwartz 2019, 18-24). Likewise, in Israel, the state assumes responsibility when a public official has negligently inflicted a loss when executing her public powers, while an immunity from liability is extended to the public official (S. 7A(a) of the Tort Ordinance 1968; State Attorney Directive 16.5 2003).

${ }^{15}$ This conclusion might have been different if only one precondition was not entirely met with, in which case while optimal deterrence would not be likely to be achieved, under- and overdeterrence might have been. 
${ }^{16}$ Such factors could include, for example, political clout, sufficient independence from other actors, and reputational concerns.

${ }^{17}$ Conscription to the IDF is mandatory for Israeli citizens over the age of 18 , unless there are medical or religious exceptions. The duration of active mandatory service ranges between two to three years, depending on individuals' sex and date of enlistment. Upon completion of mandatory service, combatants are required to continue to serve in reserve duty until the age of 45 (Sections 13-16, 36A of the Security Service Act 1986).

${ }^{18}$ Mainly through location (combatants' training base, and borders), unit tags, and combatant recruitment dates.

${ }^{19}$ MK Major General IDF2 was also a Minister.

${ }^{20}$ The state is immune from liability due to the combatant activities exception. Moreover, public officials, including combatants, are immune to tort liability if they inflicted an injury while acting within their public powers (S. 7A(a-b) of the Tort Ordinance 1968). Even when a public official is not immune from liability, but her actions are nonetheless a result of the use of her public powers, the state assumes the responsibility for tort liability (State Attorney Directive 16.5 2003, 2-4).

${ }^{21}$ On August 18, 1988, an undercover military force arrived at Tammun town in the West Bank for the purpose of arresting suspects. Three Palestinian men spotted the force and ran away from it. In response, the force opened fire at the men, in breach of the Rules of Engagement. Consequently, one of the men died, and the others were wounded (Bani Uda v. Israel, 9).

${ }^{22}$ Justice Barak adopted the opinion of Reinhardt J. as it was articulated in the Koohi case, who held that tort law's rationales are inapplicable to war (Koohi v. United States, 17).

${ }^{23}$ Justice Barak set a six factors test, according to which courts can establish whether the exception applies: 1) the risk that the forces were exposed to; 2) the weapons used; 3) the purpose of the 
activity; 4) the location of the activity; 5) the duration of the activity; 6) the type of forces engaged in the activity (Bani Uda v. Israel, 7-9).

${ }^{24}$ A survey of 292 cases between 1952 and 2021, in which the courts ruled on the applicability of the combatant activities exception shows that the amendments to the exception narrowed its scope. Until the second Intifada in late 2000, the courts found the exception to be inapplicable in $70 \%$ of cases. This number dropped during the second Intifada and following Amendment 4 to 39\%, and in the years following Amendment 7 it was reduced further to 19\%. After Amendment 8 the exception was found to be inapplicable in only $13 \%$ of cases. An analysis of the cases reveals that the Jerusalem courts found the exception to be applicable in $76 \%$ of cases $(\mathrm{N}=127)$, and the South courts reached a similar finding in $98 \%$ of all cases $(\mathrm{N}=40)$. By comparison, the Supreme Court had a positive finding of the exception's applicability in only $61 \%$ of all cases $(\mathrm{N}=28)$, and in the Tel Aviv courts this number falls to $43 \%$ ( $\mathrm{N}=14)$.

${ }^{25}$ This department provides guidance on the interpretation of the law to governmental bodies, including the district and state attorneys, and oversees the drafting process of Bills.

${ }^{26}$ A paired-samples t-test was used to determine whether there was a statistically significant mean difference between deterrence level when liability was imposed on the state and when liability was to be borne by the combatants themselves. Participants were more deterred when presented with the possibility that they would bear liability for compensation (Vignette A: $64.951 \pm 1.955$; Vignette B: $58.302 \pm 2.383$; Vignette C: $71.099 \pm 2.315$ ) as opposed to the state being liable (Vignette A: $37.019 \pm 1.797$; Vignette B: $33.766 \pm 2.088$; Vignette C: $42.689 \pm 2.287$ ). There is a statistically significant increase of 27.932, $t(286)=14.156, p<.0001$ in Vignette A; 24.536, $t(232)$ $=11.395, p<.0001$ in Vignette $\mathrm{B}$; and $28.410, t(216)=12.931, p<.0001$ in Vignette $\mathrm{C}$. Additionally, a paired-samples t-test was used to determine whether there was a statistically 
significant mean difference between deterrence levels when liability was owed to the State's civilians or to enemy civilians. Participants were more deterred when presented with the possibility that liability for compensation was owed to enemy civilians (Vignette A: 53.259 \pm 1.820 ; Vignette B: $48.272 \pm 2.216$; Vignette C: $59.364 \pm 2.276$ ) as opposed to the State's own civilians (Vignette A: $48.710 \pm 1.689$; Vignette B: $43.796 \pm 2.033$; Vignette C: $54.423 \pm 2.083)$. There is a statistically significant increase of 4.548, $t(286)=3.117, p<.0001$ in Vignette A; 4.476, $t(232)=2.751, p<$ .001 in Vignette B; and 4.940, $t(216)=3.010, p<.001$ in Vignette C.

${ }^{27}$ A one-way repeated measures ANOVA was conducted to determine whether there were statistically significant differences in level of deterrence when participants were presented with no information regarding the amount of compensation, when they were told the amount would be 500 ILS, and when they were told the amount would be 5 million ILS. The amount of compensation elicited statistically significant changes in level of deterrence, $F(2,432)=44.92, p<.0001$, with deterrence levels decreasing from $51.16 \pm 26.94$ when no liability amount was specified to 46.03 \pm 29.99 when liability amount was said to be 500 ILS, and it increased to $56.89 \pm 29.78$ when liability was said to be 5 million ILS. Post hoc analysis with a Bonferroni adjustment revealed that there is statistical significance when deterrence level was decreased from no amount of liability specified to 500 ILS liability $(-4.83 \pm 1.298, p<.0001)$, and when it increase from no amount of liability specified to 5 million ILS $(7.38 \pm 1.298, p=.0001)$, and from liability of 500 ILS to 5 million ILS $(12.21 \pm 1.298, p<.0001)$.

${ }^{28}$ In the Adallah case, the Supreme Court of Israel ruled that part of the combatant activities exception is unconstitutional, as it infringes the constitutional right to property by barring all tort cases that arise in a territory that was proclaimed as hostile (Adallah v. Minister of Defense). 
However, in the $A v$. Israel case, the District Court of Be'er Sheva ruled that the exception is constitutional despite its denial of remedies to enemy subjects.

${ }^{29}$ These include a mandatory notice no later than 60 days from the date in which the loss was inflicted and a two-years limitation period instead of seven (Section 5A(2-3) of the Civil Wrongs (State Liability) Act 1952); demanding security bonds that price-out most potential Palestinian plaintiffs (Bachar 2017, 849-51); and requiring that submission of claims will be done to either the Jerusalem or South District Courts (Section 5B1 of the Civil Wrongs (State Liability) Act 1952). ${ }^{30}$ The Supreme Court of Israel denied a petition against the State Attorney's directive that prohibits granting entry permits to Palestinians who are residents of the Gaza Strip, except when an exceptional humanitarian need arises (Abu Dakah v. Minister of Interior).

${ }^{31}$ In two other cases, petitions to the Supreme Court prompted the IDF to change its practices before the court could rule on the subject-matter, thus the IDF avoided a precedent that would constrict its ability to act. In the Hass case, the IDF stopped using white phosphorus munitions, and in the Doctors for Human Rights case the IDF ceased its sonic booms practice (Hass and others v. The Chief of Staff; Doctors for Human Rights v. The Minister of Defense).

${ }^{32}$ For example, an instrumentalist legal scholar can argue that as the findings of my research suggest that tort law is likely to under-deter state actors from engaging in wrongful combatant activities during warfare than the most economically efficient solution would not be to abolish the combatant activities exception but to install blanket immunity from tort liability in this context. However, in adopting this approach we are bound to lose tort law's other qualities, such as the ability to nudge public actors, correct wrongs, and empower plaintiffs to stand on their rights. For a further analysis, see approaches and sources in supra note 9. 